\title{
Las tradiciones proféticas y el proyecto de liberación*
}

\author{
Rafael de Sivatte \\ Departamento de Teología \\ San Salvador, El Salvador
}

En las décadas de 1960 y 1980, en muchos de nuestros pueblos del llamado "tercer mundo", dominados por regímenes militares y por un sistema político y económico de corte capitalista, se hablaba con frecuencia de impulsar proyectos de liberación. Era algo común. ¿Qué pasó cuando estos pueblos salieron de tales situaciones, "alcanzaron la libertad" y comenzaron a ser gobernados en "democracias formales"? ¿Se alcanzó realmente la liberación? La respuesta es "formalmente" afirmativa, pero si se analiza con cuidado la realidad, se cae en la cuenta de que esa liberación dejaba y sigue dejando mucho que desear. Más aún, si se piensa en el proyecto de liberación integral de todos los pueblos y de toda la humanidad que Dios tiene en mente, y si se examina con cuidado la visión utópica que de ese proyecto tienen las tradiciones proféticas de Israel. Los profetas adquieren conciencia del proyecto liberador de Dios y de sus sueños, a lo largo de la historia de su pueblo.

Aquí, intentaré mostrar cómo las tradiciones proféticas de Israel fueron comprendiendo y formulando el proyecto liberador de Dios y cómo estas actualizaciones proféticas están muy relacionadas con las situaciones de nuestros pueblos y de la humanidad, en el pasado reciente y en el presente. Comenzaré, sin embargo, examinando el momento fundante del pueblo de Dios, Israel, y su relación con el proyecto liberador.

* Este artículo es un complemento, desarrollo y ampliación de otros artículos míos anteriores publicados en esta revista. 


\section{La liberación del dominio opresor, experiencia fundante del pueblo de Dios}

Es bien conocido que, en torno al año 1100 a. C., en la zona central y en el sur de Canaán, se reunieron varios grupos, que habían estado en Egipto de diferentes modos y por diferentes razones. Algunos habían sido expulsados, en torno al año 1550 a. C., por el faraón Ameni (Amenemhet I), cuando este consiguió acabar con el dominio de los hiksos, invasores procedentes de Asia, que habían favorecido la inmigración de pueblos extranjeros. Otros salieron de manera regular, a raíz de los hechos ocurridos en el año 1350 a. C. Amenofis IV abandonó la zona del delta y trasladó su capital a la zona media de Egipto (Tell el Amarna o Ikhet Aton), que convirtió en la ciudad sagrada del nuevo dios único Atón. Entonces, el delta, zona de asentamiento de muchos grupos de inmigrantes, cayó en la depresión económica. El desempleo provocó la emigración de muchos grupos hacia otros países y zonas con mejores posibilidades económicas. El faraón favoreció esa emigración.

Un tercer grupo consigue huir, en torno al año 1250 a. C., en tiempos de Ramsés II y su sucesor. El gasto público y los pocos ingresos empobrecieron al país y provocaron una crisis económica. Aumentó el desempleo y la explotación de la fuerza de trabajo, obligada a laborar por un salario cada vez más bajo. Muchos grupos buscaron cómo huir. Posiblemente, aprovecharon algunos fenómenos naturales, como las llamadas plagas, o el cambio de la situación del país, como la muerte del primogénito del faraón.

Los expulsados, emigrantes y huidos de Egipto se fueron encontrando, en la zona de Canaán, con algunos grupos de pasado nomádico (desierto de Judá) y medio sedentario (en torno al oasis de Beersheba), los cuales, de algún modo, habían vivido también bajo el dominio egipcio. Los egipcios y sus ejércitos están presentes en el Creciente fértil (Egipto, franja siro-cananea y Mesopotamia).

Los grupos más afines, con experiencias vitales semejantes, comenzaron un largo proceso de unificación, sobre todo, en el centro y el sur de Canaán. Así, formaron un pueblo, que comenzó a ser conocido como Israel, por uno de los antepasados de un grupo importante de emigrantes, que había regresado de Egipto. Todos ellos captaron que hubo algo que había marcado especialmente su existencia pasada y también actual. Es decir, el haber salido de Egipto y el haber vivido, de alguna manera, la dominación de Egipto y la liberación de dicho dominio.

La unión incipiente se consolidó con la organización monárquica de David y Salomón. La construcción del palacio del rey, de las fortalezas y del templo, y la formación de un ejército contribuyeron a ello.

Israel surgió consciente de que la liberación del dominio egipcio y la concentración en Canaán eran claves para entender su existencia, así como el 
descubrimiento de que en este proceso, los dioses paternos de los nómadas, los dioses de la tierra y el dios del oasis de Qadesh Barnea y de la montaña del Sinaí habían estado presentes, acompañándolos y animándolos a formar aquel pueblo, con vocación de ser testimonio ante otros pueblos de que Dios es liberador y defensor del pequeño, y de que es posible vivir de otro modo: como pueblo libre, fraternal, justo, solidario y pacífico.

La experiencia de ese pueblo ha quedado registrada en muchos textos de acción de gracias, de alabanza, de reflexión y, sobre todo, de profesión y constatación de las grandes acciones de Dios, las cuales justifican el modo de vida y de celebración del pueblo, y motivan la opción por ese Dios.

Textos como Éxodo 15, Jueces 5, Salmos 136, Salmos 78, Judit 5, Nehemías y, sobre todo, Deuteronomio 6,20-25, Deuteronomio 26,1-11 y Josué 24,1-15 dan testimonio de esas acciones de Yahvé, las cuales se convirtieron en experiencias de su presencia en la historia. En todos ellos se recuerdan siempre las acciones de Dios para sacar al pueblo de Egipto y conducirlo a la tierra, aunque se observan variaciones, ampliaciones y acentos diferentes. Por ejemplo, la experiencia se formula con diferentes géneros literarios - acción de gracias, alabanza, llamada a reflexionar, profesión de fe, llamada a optar. Las acciones de Dios se amplían añadiendo otras - los orígenes, los antepasados, el paso por el desierto- o explicando cada vez con más detalles - las historias de los patriarcas, la situación y la salida de Egipto, las plagas, el mar Rojo, las aventuras en el desierto y la montaña del Sinaí, y la entrada en la tierra. Algunos aspectos son acentuados - lo que para unos fue salvación, para otros fue muerte; la reacción negativa del pueblo, en contraposición a la fidelidad de Dios, la imposibilidad de vencer a este pueblo de Dios, si se mantiene fiel a él.

La salida de Egipto, el ingreso a la tierra y la constitución del pueblo de la alianza, es decir, alternativo, se convierte en la experiencia más importante de todos esos grupos, una experiencia compartida y, por tanto, unificadora. La formulación narrativa se encuentra en Éxodo 3,1-15. De ahí la conveniencia de analizar esa narración con detenimiento.

El Dios de los antepasados -Abraham, Isaac y Jacob - se le hace presente a Moisès misteriosamente, en el monte, como una zarza que arde, sin consumirse - posiblemente en relación con el fuego sagrado del templo, que será el símbolo de la presencia del Dios. Ese Dios comparte con Moisés cómo ve la realidad de los grupos oprimidos, unos grupos que no cuentan, que son títeres en manos de sus opresores, que se lamentan y claman, porque se sienten menos que nada. Le manifiesta que se siente afectado, en el fondo de sus entrañas, y, por tanto, que no soporta esa situación. En consecuencia, le pide acompañar a esos grupos y ayudarlos a salir de la situación de opresión, para que puedan formar un pueblo nuevo, donde no haya injusticia, ni opresión, ni marginación. Ante las dificultades presentadas por Moisés para cumplir con esa misión - no es nadie 
para iniciar una obra tan grandiosa, el poder opresor seguramente no le prestará atención cuando pida la libertad de los grupos y que tanto él como los oprimidos desean conocer su nombre, para estar seguros de que estará con ellos cuando lo invoquen-, Dios responde que debe confiar. Él se compromete a estar a su lado y al lado de los grupos, en ese camino de liberación.

Así, pues, en el origen del llamado pueblo de Dios está el descubrimiento de un Dios cuyas entrañas de misericordia no soportan el clamor de las personas maltratadas, marginadas y excluidas, porque desea una sociedad diferente, alternativa, fraterna, justa, solidaria y basada en la misericordia.

Al principio, quizás esa manera alternativa de vivir no representó una dificultad especial, porque todavía estaba muy viva la presencia de este Dios liberador. Además, era un pueblo con perspectiva nómada, donde es más importante el bienestar del grupo que el interés personal de cualquiera de sus integrantes. Prueba de ello es que la tierra es repartida de manera proporcional entre las familias. El reparto se hace por suertes, para dejarlo a la voluntad de Dios, y está prohibido vender, donar o canjear la tierra familiar, para evitar la acumulación en unos pocos.

\section{La crisis del proyecto liberador}

La crisis comienza cuando Israel se vuelve sedentario y se organiza como monarquía; cuando compite con otros países por la adquisición de nuevas tierras, riquezas y poder; cuando la tierra se revaloriza y se utiliza para pagar al ejército, que las había conquistado; cuando la economía, basada en el capital y el consumo, crece; cuando surgen la propiedad privada, la profesionalización del comercio y de la justicia, la banca, la privatización, el aumento del gasto público, la obligación de servir periódicamente en la corte del rey y en el templo, la ambición de poseer y acumular tierra, la necesidad de dinero para consumir, el préstamo bancario, que con frecuencia se convierte en esclavitud, el egoísmo, la irresponsabilidad de las autoridades; cuando los reyes hacen alianzas con los imperios o con los pequeños reinos vecinos, creyendo que eso les daría seguridad; cuando ponen su confianza en las armas y comienza una carrera armamentística.

De esa manera, se crea una situación no querida por Dios. Estallan guerras y los gobernantes favorecen a quien los apoya, mientras se olvidan de los débiles. Las alianzas con otros países imponen condiciones de servidumbre. Algunos grupos sociales - los militares, los sacerdotes, los banqueros, los comerciantes, los jueces y los burócratas - dominan a los otros sectores - agricultores, huérfanos, viudas, los sin tierra y los emigrantes.

¿Para esto había acompañado Dios a los grupos, en el proceso de liberación y de formación de un nuevo pueblo testimonial? De ninguna manera. Dios seguía 
soñando en su proyecto liberador y alternativo. Por eso, comienza a enviar a los profetas, cuyas actividades y palabras han quedado recogidas en las tradiciones proféticas.

Es verdad que, a lo largo de la historia del pueblo de Dios, hay momentos en que los reyes, los máximos responsables de la marcha del país, desean reformarlo para asemejarlo al país soñado por Dios. Este es el caso de las llamadas reformas de Ezequías (hacia el 715 a. C.) y de Josías (hacia el año 625 a. C.), quienes pretendieron volver al espíritu del Dios del éxodo y al estilo del pueblo y de la humanidad soñados por él.

Pero también es verdad que la mayoría de los reyes de Israel y de Judá son los primeros responsables de que las cosas no caminaran como Dios quería. Dos casos típicos son los reyes David (1000 a. C.) y Ajab (850 a. C.). Como es bien sabido, David se encaprichó con la mujer de Urías, cometió adulterio con ella, puso las condiciones para que Urías muriera en combate y se quedó con su mujer. Ajab, por su lado, desea el campo de su vecino Nabot y como este no se lo quiere vender o cambiar por otro, ya que se trata de un campo familiar, consigue que este sea declarado traidor y condenado a muerte. Así, pudo quedarse con el terreno.

Lo ocurrido después también es conocido. En ambos casos aparecen dos personajes que, en nombre de Dios, condenan tajantemente la conducta de esos reyes y los amenazan duramente. Natán ataca a David, lo denuncia y le explica con claridad cuál es la postura de Dios ante su acción criminal. Lo hace mediante la clarificadora parábola de 2 Samuel 12,1-4, que narra cómo un rico, que tiene una gran cantidad de ovejas, se apropia de la única oveja que posee un pobre para agasajar a una visita. David reacciona con fuerza: el rico, "por haber hecho semejante cosa y no haber tenido compasión", merece la pena de muerte ( $2 \mathrm{Sm} \mathrm{12,6).} \mathrm{Entonces,} \mathrm{Natán} \mathrm{le} \mathrm{hace} \mathrm{ver} \mathrm{que} \mathrm{es} \mathrm{él} \mathrm{quien} \mathrm{ha} \mathrm{obrado} \mathrm{como} \mathrm{el} \mathrm{rico}$ de la parábola y lo amenaza. Le deja claro que Dios no puede soportar ese tipo de acciones (2 Sm 12,7-12). Elías, a su vez, se enfrenta abiertamente con Ajab y Jezabel y los acusa de asesinato y usurpación, y les anuncia el fin de su dinastía $(1 \operatorname{Re} 21,17-22)$.

Pues bien, si esta es la conducta de los responsables de mantener el proyecto liberador de Dios, ¿qué no hacen sus súbditos? Por esa razón, los profetas desenmascaran constantemente esas actitudes y esos actos de las autoridades y del pueblo de Dios.

\section{Las tradiciones proféticas de Israel}

Los profetas son llamados y enviados por Dios para denunciar todo aquello que se opone a su proyecto liberador y para defender su sueño: un pueblo en paz, en justicia y en solidaridad. De la misma manera en que ese proyecto se puede resumir en "amar a Dios con todo el corazón... y al prójimo como a uno mismo", 
porque ambos mandatos están en íntima conexión y porque no puede darse el uno sin el otro, el proyecto contrario se puede sintetizar en "la búsqueda y el amor a otros dioses, o la falsa concepción de Dios, que llevará, inexorablemente, a una relación egocéntrica con el prójimo".

Aquí me detendré en los profetas, pero sin desconocer que hay otros grupos que, a su modo, también defienden el proyecto liberador de Dios. Los profetas desenmascaran continuamente los intentos para romper o contradecir el proyecto de Dios. Los desenmascaramientos más importantes son la búsqueda de otros dioses o de presuntas seguridades, el intento de manipular a Dios, la divinización e idolatría del poder, la injusticia social o la ruptura de la fraternidad, el particularismo o la cerrazón de Israel.

\subsection{La búsqueda de otros dioses o seguridades}

El pueblo de Israel cae en la tentación de buscar a otros "dioses" que le den seguridad, cuando se encuentra en dificultades. No se trata tanto de imágenes de piedra, barro o madera de otros dioses, como de convertir en dioses realidades de la vida diaria.

En el Creciente fértil se alternan diferentes imperios, con los cuales Israel forzosamente debe relacionarse. Los imperios buscan que países pequeños como Israel acepten el vasallaje incondicional. A veces, simplemente los someten y los convierten en provincias del imperio. En otras ocasiones, los países pequeños buscan la alianza con esos imperios, por conveniencia de sus gobernantes o de quienes pretenden alcanzar el poder.

Los profetas adoptan tres posturas ante el imperio. La primera es una aparente compatibilidad entre este y la voluntad de Dios. Dado que Dios es Señor de la historia y que nada escapa a su providencia, muchos profetas consideran que la simple existencia del imperio es obra de su voluntad. Tienen claro, sin embargo, que el dominio imperial es limitado en intensidad y tiempo. Por tanto, Dios no permitiría una dominación imperial excesiva ni duradera. En último término, el sueño de Dios consiste en un mundo sin imperios.

Veamos algunos casos concretos. El profeta Isaías se enfrenta al imperio asirio. Hacia el año 735 a. C., cuando Israel y Siria declaran la guerra a Judá y marchan sobre Jerusalén, porque su rey no acepta formar parte de la coalición contra Asiria, el rey Ajaz, atemorizado, pide ayuda al emperador de Asiria. Ante esto, el profeta denuncia al rey y lo acusa de cansar a los seres humanos y a Dios mismo (véase Is 7,10-17). Y añade que Dios utilizará a Asiria para regañar a Judá - “el Señor afeitará con la navaja alquilada más allá del río la cabeza y el pelo de los pies, la barba y todo", 7,20; "el Señor hará subir contra ellos las aguas del río. Desbordará, invadirá todas las riberas de Judá hasta llegar el agua al cuello", 
8,5-8a. Así, pues, Isaías se refiere a Asiria como instrumento de castigo y "como el bastón de la ira y el furor de Dios" (10,5-6).

Pero el profeta cambia su lenguaje a raíz de la invasión de Senaquerib, hacia el 701 a. C. (ver Is $10,5-19 ; 14,3-27$ ). Entresaco un par de textos en los que aparece con claridad este cambio.

Yahvé ha jurado esto: Cierto, lo que he pensado, será un hecho, lo que he decidido se realizará. Quebrantaré a Asiria en mi tierra, sobre mis montes la pisotearé (Is 14,20-25).

Porque un poquito más y se habrá consumado el furor; mi ira se habrá calmado del todo. Entonces, Yahvé provocará contra ellos [los asirios] una calamidad (Is 10,25-26).

Posiblemente, el cambio se debe a las blasfemias, la arrogancia y la soberbia de Asur, tal como aparece en Isaías 10,11 — “No voy a tratar a Jerusalén y sus imágenes como ya traté a Samaría y sus ídolos?". Asimismo, por propasarse en la tarea encomendada por el Señor - "se propone destruir y suprimir" $(10,7)-$ y por pretender atacar a todas las naciones (ver Is 10,6-7.13-14), en contra de lo que su Señor querría. Por eso, Isaías añade: "AAcaso se jacta el hacha frente al que corta con ella? ¿O se tiene por más grande la sierra que el que la blande? ¡Como si la vara dirigiese a quien la sostiene!" $(10,15)$.

En conclusión, aunque Isaías parece aceptar, en principio, un dominio moderado y transitorio del instrumento, en último término, mantiene una postura utópica de no aceptar el imperio. Esto queda claro en Isaías 2,1-4.

Sucederá en días futuros que firme será el monte de la Casa de Yahvé en la cabeza de los montes y se alzará desde [por encima de] las colinas y confluirán a él todas las gentes [goyim: naciones extrañas a Israel, paganos] y acudirán pueblos [ammim] numerosos y dirán: "Vengan y subamos al monte de Yahvé, a la Casa del Dios de Jacob, y él nos enseñará [sobre] sus caminos y nosotros seguiremos en sus senderos". Pues de Sion saldrá la Ley, y de Jerusalén la palabra de Yahvé. Y juzgará entre las gentes [goyim], y arbitrará para pueblos [ammim] numerosos. Y destruirá sus espadas para [convertirlas en] azadones y sus lanzas para [convertirlas en] podaderas. No levantará una espada gente [goy] a [contra] gente [goy] y no aprenderán más guerra.

El segundo caso es el de Ezequiel y Jeremías. Ezequiel denuncia al rey Sedecías por haber roto el pacto con Babilonia, que en ese momento es considerada un instrumento de Yahvé para gobernar al mundo (ver Ez 17,1-21). Jeremías, por su parte, llama a Nabucodonosor "siervo de Dios", cuya misión temporal es castigar a Judá. En consecuencia, pide rogar por él y someterse a él, porque, en ese momento, Dios le había sometido todo (ver Jr 25,8-11; 27,5-6.11-12,17; 29,4-9). 
Jeremías acaba diciendo que el plan de Dios es de salvación y, por tanto, al imperio de Nabucodonosor también le llegará su momento. Varios textos así lo dicen: "Cuando se hayan cumplido setenta años, castigaré a aquella gente [Babilonia] haciendo de ella una ruina" $(25,12)$; "hasta que llegue también la hora a ese país y muchas naciones y reyes lo reduzcan a esclavitud" (27,7); "Cuando se hayan cumplido los setenta años de Babilonia, intervendré a favor de ustedes y realizaré la promesa de devolverles a este lugar" $(29,10)$.

En un acto simbólico, Jeremías encarga a un amigo, de viaje a Babilonia, que proclame las palabras de amenaza contenidas en un rollo y que luego lo lance atado a una piedra en medio del río, y diga: "De este modo, se hundirá Babilonia y no volverá a flotar" (ver Jr 51,61-64).

El tercer caso es el del Segundo Isaías, que llama a Ciro pastor, ungido, amigo de Dios, siervo de Dios y enviado por Dios para liberar al pueblo (ver Is $41,1-5 ; 45,1-8 ; 48,12-15)$. En resumen, los cuatro profetas hablan de los imperios como instrumentos y siervos de Dios, pero de un modo crítico. Al final, rechazan la opresión unida a cualquier imperio.

La segunda postura es de rechazo nacionalista del imperio. No deja de ser llamativo que los profetas Sofonías y, sobre todo, Nahum no digan nada negativo o crítico de Judá. Sin embargo, son muy hostiles y odian a otros pueblos, en especial, a Asiria. También los profetas anónimos, contemporáneos de Jeremías, llaman la atención por el odio con el que anuncian la caída de Babilonia (ver Jr 50-51; Is 13; 21,1-10; 47). En los mismos términos hablan Zacarías y Ageo de los imperios, incluido el medo-persa. Los dos desean que se destruyan entre sí o se autodestruyan. Así, pues, estos profetas tienen una postura antiimperialista, aunque esta puede ser algo interesada y nacionalista, ya que enfatizan que su rechazo se basa en que esos imperios han hecho daño a Judá.

La tercera postura es el rechazo del imperialismo en cuanto tal. Aun cuando todos los profetas acaban diciendo que los imperios no tienen la última palabra, algunos de ellos lo dicen con total claridad. Este es el caso de algunos profetas anónimos, contemporáneos de Jeremías, que afirman, en nombre de Dios y en relación a Babilonia: "Aquí me tienes contra ti, montaña destructora, la que ha destruido toda la tierra [...]; te convertiré en una montaña de cenizas" (Jr 51,25). En esto, siguen la línea de Isaías 14,13-14, cuando afirma que el imperio, al gloriarse de "escalar los cielos", de "sentarse en la montaña de la asamblea", de "subirse sobre una nube", de "ser igual al altísimo", prepara su destrucción.

Habacuc, por su parte, constata que la solución de las situaciones de injusticia no consiste en que un imperio destruya al responsable de ella o que se imponga al imperio injusto, porque, en su opinión, todo imperio es hostil y destructor, y finalmente, será destruido (ver Ha 2,2-5.6-20). En este caso, los profetas rechazan el imperialismo, no desde una perspectiva nacionalista, sino ética. Lo rechazaban 
por su bestialidad, por su espíritu destructor y por su ansia de dominio del mundo. En esta línea se encuentra la visión apocalíptica de la historia, según la cual los imperios se han sucedido unos a otros, hasta que todos ellos sean destruidos por el imperio del Hijo del Hombre o de los Santos del Altísimo.

En síntesis, un grupo de profetas habría rechazado totalmente al imperio, porque ambicionan un dominio "divino", absoluto, sobre las naciones; porque usan medios inhumanos, antiéticos, para conseguir sus fines; porque no se limitan a purificar, sino que también destruyen; porque se consideran definitivos, como si fueran dioses; porque son víctimas de su arrogancia vacía y sin fundamento; y porque siempre se convierten en realidades inhumanas y bestiales. La posición de los profetas es, en definitiva, utópica. Sueñan con un mundo sin naciones opresoras e imperialistas y con un mundo justo y solidario.

Conviene preguntarse ahora qué juicio hacen los profetas de las alianzas de Israel y de Judá con los imperios. Las alianzas, y el juicio profético, ocurren en tres circunstancias. La primera es la alianza de los reyes de Israel y la postura de Oseas. El rey Menahem ofrece tributar a Asiria, a cambio de apoyo y de permanecer en el poder. Asimismo, el rey Oseas pide ayuda a Asiria en su golpe de Estado contra Pecajías, para alcanzar el poder. Años después, este rey se acerca a Egipto, en busca de ayuda para independizarse de Asiria. Estas alianzas provocan la intervención de los imperios y el fin de la existencia de Israel como reino.

Frente a ellas, el profeta Oseas dijo que buscar solución a los problemas internos en Asiria o Egipto era inútil, porque solo Yahvé tiene el señorío: "Yo me portaré como un león con Efraín, y como un cachorro con la gente de Judá. Yo sí, yo mismo lanzaré un zarpazo y huiré, me llevaré mi presa y nadie me la podrá quitar. Pero ahora me vuelvo a mi casa, hasta que se reconozcan culpables y vengan a verme, pues en su angustia tratarán de encontrarme" (Os 5,13-15).

Y añadió que la alternativa de las alianzas es idolátrica y no lleva a ninguna parte más que a la autodestrucción.

Efraín se mezcla con otros pueblos. Efraín es una torta que se ha quemado por un solo lado. Los extranjeros consumen sus energías sin que se dé cuenta; su cabeza está sembrada de canas y no lo nota. Su misma arrogancia condena a Israel, pues a pesar de todo, no se ha vuelto a Yahvé, su Dios, ni trata de buscarlo. Efraín es como una paloma tonta y sin juicio, pues o bien llama a Egipto, o bien se dirige a Asiria. Pues bien, adonde quiera que vaya, yo le pondré una trampa y caerá en ella, como las aves del cielo (Os 7,8-12).

En realidad, las alianzas acaban comiéndose al país que las buscó. Así lo dice claramente Oseas:

Como siembran vientos, cosecharán tempestades. Su grano de trigo no echará espigas, la espiga no dará harina y, si llega a dar algo, se la comerán 
los extranjeros. Israel ha sido devorado y se ha convertido en medio de las naciones en algo que no sirve para nada. Efraín era un burro orgulloso. Pero miren cómo subió a Asiria llevando regalos a sus amantes. Sin embargo, por más que se haya ganado amigos entre las naciones, pronto lo voy a dispersar y no podrá ungir más reyes ni príncipes (Os 8,7-10).

Las alianzas con Asiria y Egipto, en las cuales Israel confía, se basan en la falsedad, pues llega a considerar a ambos imperios como dioses. Por eso, la única alternativa es la destrucción (ver Os 8,$14 ; 12,1-2$ ). La confianza en esas alianzas y en la fuerza de las armas y las fortificaciones lleva a la ruina: "Olvida Israel a su Hacedor, y edifica templos; Judá multiplica ciudades fortificadas. Pero yo prenderé fuego a sus ciudades, que devorará sus palacios" $(8,14)$. Convertir al imperio en dios y establecer alianza con él es un engaño.

Efraín me ha rodeado de mentira, la gente de Israel de falsedad [...]. Efraín se llena de viento, corre tras el viento de oriente, sin cesar multiplica la mentira y la violencia, hace alianza con Asiria y lleva perfumes a Egipto (Os 12,1-2).

Por esa razón, la auténtica conversión pasa por el rechazo de las alianzas y los ídolos, y por la confesión del Dios misericordioso.

Asiria no nos salvará ni confiaremos más en los caballos, ni a la estatua que hicieron nuestras manos volveremos a decirle "Dios nuestro", oh, tú, en quien halla compasión el huérfano (Os 14,4).

La segunda circunstancia es la alianza de los reyes de Judá con Asiria y Egipto, y la reacción de Isaías. Hacia el año 736 a. C., el Creciente fértil se caracteriza por varias tensiones. Egipto intenta coaligarse con Siria (o Aram), Israel (o Efraín), los reinos filisteos y Judá, contra el poderoso imperio asirio. Pero el rey de Judá, aconsejado por Isaías, no acepta formar parte de dicha coalición. La negativa provoca la guerra de Siria-Israel contra Judá para presionarlo a integrarse en la coalición. Entonces, el rey de Judá se alía con el imperio asirio. Años después, hacia el 705 a. C., siendo rey Ezequías, Egipto vuelve a presionar a Judá para que se rebele contra el imperio asirio.

Isaías, cuya postura remite a su fe, declara que esas alianzas suponen convertir a los imperios en dioses. Por tanto, son alianzas idolátricas, que confían en un engaño, e implican una rebelión contra Dios, quien, al final, provocaría su caída. Esta postura de Isaías aparece claramente en dos textos dedicados a la cuestión de las alianzas.

En el primero, en Isaías 30,1-5, se lee:

¡Ay de estos hijos rebeldes, dice Yahvé, que ponen en práctica unos proyectos que no son los míos y que se comprometen con pactos que no les he sugerido, de modo que acumulan así pecados y más pecados. Han partido para Egipto, sin escuchar mis consejos, para pedirle asilo al faraón y refugiarse bajo 
la sombra de Egipto. Ustedes esperan la protección del faraón, pero serán defraudados y se avergonzarán de haber buscado la sombra de Egipto. Pues sus ministros han ido a Zoan, y sus embajadores han llegado hasta Hanes. Todos han traído regalos a un pueblo que no les servirá de nada y que no les conseguirá ni ayuda ni socorro, sino deshonra y malos ratos.

Y en el segundo, en Isaías 31,1-3, se dice:

¡Ay, los que bajan a Egipto por ayuda! En la caballería se apoyan, y fían en los carros porque abundan y en los jinetes porque son muchos; mas no han puesto su mirada en el Santo de Israel, ni a Yahvé han buscado. Pero también él es sabio, hará venir el mal, y no retirará sus palabras; se levantará contra la casa de los malhechores y contra la ayuda de los que obran la iniquidad. En cuanto a Egipto, es humano, no divino, y sus caballos, carne, y no espíritu; Yahvé extenderá su mano, tropezará el ayudador y caerá el ayudado, y todos a una perecerán.

En estos dos textos, es interesante observar una serie de expresiones de Isaías, que indican por qué esas alianzas no solo son políticamente inapropiadas e inútiles, sino que, además, son idolátricas, porque piensan que esos imperios y sus armas son divinos. Esas expresiones son las siguientes: "Han partido para Egipto [...], para pedirle asilo al faraón y refugiarse bajo la sombra de Egipto. Ustedes esperan la protección del faraón [...] y se avergonzarán de haber buscado la sombra de Egipto. Pues sus ministros [...] han traído regalos a un pueblo que no les servirá de nada y que no les conseguirá ni ayuda ni socorro, sino deshonra y malos ratos”. “¡Ay, los que bajan a Egipto por ayuda! En la caballería se apoyan, y fían en los carros [...]; mas no han puesto su mirada en el Santo de Israel, ni a Yahvé han buscado. [...]. En cuanto a Egipto, es humano, no divino, y sus caballos, carne, y no espíritu; Yahvé extenderá su mano, tropezará el ayudador y caerá el ayudado, y todos a una perecerán”. Este lenguaje es comúnmente utilizado por esa cultura para referirse a las divinidades.

En opinión de Isaías, la única alianza segura es la pactada con Yahvé. Por eso, el mismo Yahvé le dará al rey de Judá la señal de su alianza, el Emmanuel, aun cuando este dice no querer pedir señal alguna. En realidad, acaba de buscar la ayuda de Asiria. El primogénito real que está a punto de nacer es, según Isaías, signo del compromiso de Yahvé con la dinastía de David.

¡Oigan, herederos de David! ¿No les basta molestar a todos, que también quieren cansar a mi Dios? El Señor, pues, les dará esta señal: La joven está embarazada, y da a luz un hijo varón a quien le pone el nombre de Emmanuel (tú no quieres pedir señal porque esto te exigiría confiar en el Señor; prefieres, en cambio, pedir ayuda a Asiria, creyendo que te va a salvar. En realidad, solo Dios es fiel y te quiere dar la señal de que sigue estando con nosotros) (Is 7,13-14). 
La tercera circunstancia es la alianza de los reyes de Judá con Egipto y la postura de Jeremías y Ezequiel. Tanto Joaquín I como su hermano Sedecías se alían con Egipto para enfrentarse con Babilonia, lo cual lleva a la caída de Judá, a manos del imperio babilonio, y al exilio de la población del reino. Ante ello, Jeremías afirma claramente que de nada sirve hacer pactos con las potencias, porque Yahvé no está con ellas. Veámoslo en un par de textos.

¿Para qué llamas a Egipto?, ¿acaso te sanarán las aguas del Nilo? ¿Y para qué llamas a Asur?, ¿apagarán tu sed las aguas del río? (Jr 2,18).

No te des tanta prisa para cambiar tus amistades. Como te engañó Asur, también te engañará Egipto. También de ahí saldrás con las manos en la cabeza, porque Yahvé ha rechazado a aquellos en que confías, y no te irá bien con ellos (Jr 2,36-37).

Además, añadió, los imperios tienen final; confiar en ellos es ir a la nada.

Esto dice Yahvé: Maldito quien se fía de las personas y hace de las creaturas su apoyo, y de Yahvé se aparta en su corazón. Es como el tamarisco en la Arabá, y no verá el bien cuando viniere. Vive en los sequedales del desierto, en saladar inhabitable. Bendito quien se fía de Yahvé, pues no defraudará su confianza. Es como árbol plantado a la vera del agua, que enraíza junto a la corriente. No temerá cuando llegue el calor, su follaje estará frondoso; en año de sequía no se inquieta ni deja de dar fruto (Jr 17,5-8).

En todo caso, Jeremías es claro. El que tiene poder, Nabucodonosor, por ejemplo, lo tiene porque lo ha recibido de Yahvé. Por tanto, no se debe buscar ayuda en los imperios y en las alianzas militares. Los medios pacíficos son prioritarios.

Ezequiel, por su parte, habla de las alianzas con las potencias como de adulterios, que crean dependencia y acaban frustrando. Agrega que implican idolatría, pues han tomado el lugar de Dios.

Samaria, que era mía, se prostituyó, me abandonó y se enamoró locamente de los guerreros asirios, vestidos elegantemente, gobernadores y jefes, jóvenes hermosos y caballeros atléticos. Se manchó con ellos, con los más escogidos de los asirios; después de haberse enamorado de ellos, se manchó con sus idolatrías. Sin embargo, no olvido su prostitución con los egipcios; por eso, la entregué en manos de sus amantes, en poder de los asirios, de los que se había enamorado locamente. Estos la llenaron de vergüenza, le arrebataron sus hijos e hijas y, a ella, la mataron a espada. Samaria llegó a ser un ejemplo para las naciones por el escarmiento que se hizo en ella (Ez 23,5-10; cfr. $16,26-29 ; 23,11-27)$.

Así, pues, el discurso de los profetas sobre los imperios y sus alianzas tiene como punto de partida que Dios es el Señor de la historia y que tiene un plan de 
salvación. Los imperios, sin embargo, con frecuencia pretenden ocupar el lugar de Dios. Si bien, en algunas ocasiones, Dios cuenta con ellos temporalmente, como instrumentos para la realización de algún proyecto, su plan global se realizará por medios pacíficos. Por eso, la alianza con el imperio es un acto de idolatría, de prostitución y de adulterio. Esa alianza crea dependencia, pero no da seguridad y acaba en frustración, pues el imperio no tiene señorío.

De esa manera, los profetas desenmascaran los intereses egoístas de los imperios y ponen de manifiesto la certeza de que la salvación no se encuentra en alianza con ellos, sino en la conversión. En concreto, en la conversión a una vida justa, solidaria, comunicativa y participativa.

En la búsqueda de otros dioses y seguridades, las armas ocupan un lugar destacado. Frecuentemente, estas son convertidas en ídolos aparentemente confiables. Sin embargo, impiden encontrar al verdadero Dios. Israel y Judá se mueven en un entorno donde la guerra santa es común. La victoria de una nación sobre otra significa la victoria de un dios sobre otro. De ahí que las armas sean importantes hasta el extremo de tratarlas como divinidades, a las cuales se debe culto.

Ya en los libros de los llamados profetas anteriores aparece con claridad que los jueces no consiguen sus victorias con la fuerza de las armas. Así, David dice a Goliat: "Tú vienes contra mí con la espada, la lanza y las flechas, pero yo vengo a ti en nombre de Yahvé Shebaot [...] Todos [...] conocerán que Yahvé no

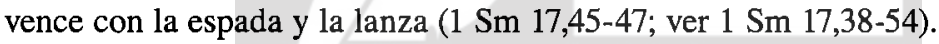

En los profetas posteriores, este es un lugar común. Continuamente afirman que confiar en las armas como si fueran dioses poderosos solo lleva a la frustración. La auténtica conversión pasa por rechazar al ídolo de las armas y por confesar comprometidamente al Dios en quien el desprotegido encuentra compasión y apoyo. Veamos algunos textos que hablan por sí mismos.

Oseas proclama: "Los salvaré por Yahvé su Dios. No los salvaré ni por el arco, ni la espada, ni la guerra, ni los caballos, ni los jinetes" (1,7b); "Israel olvidó a su autor y edificó templos; Judá multiplicó las fortalezas, pero enviaré fuego contra sus ciudades y devorará sus castillos" $(8,14)$; "Tú confías en tu poder, en la cantidad de soldados; pues bien, se alzará un tumulto de guerra en tus ciudades y todas las fortalezas serán devastadas" (10,13b-14a); "Asur no nos salvará, ya no montaremos más a caballo [ya no utilizaremos las armas de combate]. No volveremos a llamar 'Dios nuestro' a la obra de nuestras manos, porque solo en ti encuentra compasión la persona desprotegida" $(14,4)$.

Isaías dice:

No haciendo nada y sin moverse, conseguirán la victoria; en una confianza tranquila encontrarán ustedes la fuerza. Pero ustedes no han querido y han dicho: “№! ¡Usaremos los caballos para huir!”. Pues bien, huyan. Y [han 
dicho también:] “iMontaremos sobre unos rápidos carros de combate!”. Bien. También irán rápidos quienes los persigan (Os 30,15-16).

¡Ay de quienes ponen su esperanza en la caballería, que confían en el número de los carros de combate y en una caballería importante, pero no tienen en cuenta al santo de Israel y no consultan a Yahvé [...] Él se levantará [...] contra la ayuda de gente malvada [los egipcios]. Y, a que el egipcio es un ser humano y no un dios, que sus caballos [sus armas] son carne y no espíritu, cuando Yahvé se decida a actuar, tropezará quien ayuda y caerá quien es ayudado; ambos desaparecerán (Os 31,1-3).

Habacuc advierte:

Babilonia pesca a todos con anzuelo, los apresa en su red y los recoge en su bolsa. Por esto se alegra y hace fiestas. Por eso sacrifica a su red y ofrece incienso a su bolsa, pues por ellas abunda su presa, su comida es suculenta. Por eso vacía su red sin cesar, matando despiadadamente naciones (Ha 1,15-17).

Todos los profetas concluyen que las armas son como ídolos, que no pueden dar seguridad y que exigen sacrificar vidas humanas. Solo se puede confiar en Yahvé. Por esa razón, Ezequiel llama prostitutas a Samaría y a Jerusalén (ver Ez 23,5.12.15), pues "se han enamorado de personas amantes de la guerra y hábiles jinetes", "de guerreros de élite". Esto las llevará a la gran frustración, pues "vendrán contra ti del Norte con carros de combate y ruedas [...] Desde todas partes dirigirán contra ti el escudo, la armadura y el carro" (Ez 23,24). En el post-exilio, Zacarías habla de la salvación que vendrá de Zorobabel. "No es por la potencia y la fuerza, sino por mi espíritu, dice Yahvé" (Zac 4,6). Así, pues, los profetas censuran la confianza en las armas, por idolátrica. Esa confianza en un dios falso llevará a la destrucción. $Y$ añaden que solo la confianza nacida de la fe, puede salvar.

La condena de las armas es acompañada por la visión utópica de un mundo sin armas. Así, Oseas anuncia: "Aquel día haré un pacto a favor de ellos con la bestia, con el ave y con el reptil: haré desaparecer del país el arco, la espada y la guerra, y les haré reposar en paz (Os 2,20). E Isaías proclama:

Multiplicaste la alegría [...] porque el yugo que les pesaba [...] la vara del tirano has roto [...]; porque la bota militar y el uniforme de los guerreros, lleno de sangre, serán quemados; porque un niño nos ha nacido, que llevará como insignias de su señorío la sabiduría, la fortaleza, la compasión y el talante pacificador (Is 9,3-5).

Serán vecinos el lobo y el cordero [...] y un niño pequeño será su pastor [...] Nadie hará daño [...] porque la tierra estará llena de una relación profunda con Yahvé (Is 11,6-9). 
En esa misma línea, Miqueas dice: "Aquel día, suprimiré de tu sociedad los caballos y carros de combate, suprimiré las ciudades fortificadas y fortalezas, eliminaré todo aquello que está al servicio de la idolatría (Mi 5,9ss). Por consiguiente, es claro que el camino para llegar al mundo soñado por Dios es diferente. Como conclusión, puede servir bien el texto casi idéntico, en Isaías 2,2-4 y Miqueas 4,3-4.

Sucederá en días futuros que el monte de la Casa de Yahvé [...] será firme por encima de todas las colinas [...] Confluirán a él todas las naciones [...] dirán: "Ea, subamos al monte de Yahvé [...] para que él nos enseñe sus caminos [...] Pues de Sion saldrá la Ley y la palabra de Yahvé. Él hará justicia entre los pueblos [...] Forjarán de sus espadas azadones y de sus lanzas podaderas. No levantará la espada nación contra nación, ni se ejercitarán más en la guerra".

\subsection{El intento de manipular a Dios}

Uno de los intentos para romper con el proyecto de Dios es buscar un dios a la medida, un dios que pueda ser usado y manipulado, en nada parecido al Dios de la misericordia y la gracia, que se había volcado hacia los míseros y que se había comprometido voluntariamente a estar siempre a favor de y con las personas desvalidas, con su pueblo y con la humanidad.

En el pueblo de Dios se pueden observar cuatro formas para intentar manipular a Dios. La primera es la guerra santa. Los gobernantes justifican sus guerras de conquista diciendo que son santas, que Yahvé lucha a su favor y que llega el día de Yahvé, esto es, el día de la victoria para Israel y nefasto para los otros pueblos y sus dioses. Ante esa manera de pensar, Amós se pronuncia de modo muy claro, diciendo que esa aventura será un fracaso, pues nada conseguirán con esas victorias -Amós llama "Nada" a una de las ciudades conquistadas. El día de Yahvé no será un día de victoria, tal como esperan, sino un día de tinieblas, porque no vendrá a luchar a su favor, sino contra ellos.

Escuchen esta palabra que yo entono contra ustedes como elegía, casa de Israel. ¡Ha caído, no volverá ya a levantarse, la virgen de Israel; postrada está en el suelo, no hay quien la levante! Porque así dice el Señor Yahvé a la casa de Israel: la ciudad que sacaba mil a campaña quedará solo con cien, y la que sacaba cien quedará solo con diez (Am 5,1-3).

¡Ay de aquellos que suspiran por el día en que vendrá Yahvé! ¿Cómo será ese día para ustedes? Será un día de tinieblas, no de luz. Será como un hombre que huye de un león y se topa con un oso, y que al entrar en la casa apoya su mano en la pared y lo muerde una culebra. ¿No es tinieblas el Día de Yahvé, y no luz, lóbrego y sin claridad? (Am 5,18-20).

¡Ay de aquellos que se sienten seguros en Sion, y de los confiados en la montaña de Samaria, los notables de la capital de las naciones, a los que 
acude la casa de Israel! Pasen a Calnó y miren, pasen de allí a Jamat la grande, bajen luego a Gat de los filisteos. ¿Son acaso mejores que estos reinos? [...] ¡Ustedes que tratan de alejar el día funesto y en realidad acercan un estado de violencia! (Am 6,1-3).

Ustedes se ufanan por Lo-Dabar [en hebreo significa nada] y andan diciendo que son imbatibles. ¡Pues bien voy a suscitar contra ustedes, casa de Israel, una nación que los oprimirá desde la Entrada de Jamat hasta el torrente de la Arabá! (Am 6,13-14).

En esa misma línea debe interpretarse el texto del profeta campesino Miqueas, quien también denuncia la utilización de la relación de amistad con Yahvé como fuente de una falsa seguridad. "Sus jefes juzgan con soborno, sus sacerdotes enseñan a sueldo, sus profetas vaticinan por dinero, y todos dicen que son amigos de Yahvé. Por eso exclaman: ‘¿No está Yahvé en medio de nosotros? ¡No nos alcanzará ningún mal!'” (Mi 3,11-12).

También Sofonías habla de modo inesperado y chocante para Judá, del día de Yahvé.

¡Cercano está el gran Día de Yahvé, cercano, a toda prisa viene! ¡Amargo el ruido del día de Yahvé, dará gritos entonces hasta el bravo! Día de ira el día aquel, día de angustia y de aprieto, día de devastación y desolación, día de tinieblas y de oscuridad, día de nublada y densa niebla, día de trompeta y de clamor, contra las ciudades fortificadas y las torres de los ángulos. Yo pondré a los hombres en aprieto, y ellos andarán como ciegos [...]; su sangre será derramada como polvo, y su carne como excremento. Ni su plata ni su oro podrán salvarlos en el Día de la ira de Yahvé [...]; pues él hará exterminio, iy terrorífico!, de todos los habitantes de la tierra (So 1,14-18).

El mensaje de Joel es similar: "Toquen el cuerno en Sion, den gritos de alarma en mi monte santo! ¡Tiemblen todos los habitantes del país, porque llega el Día de Yahvé; está cerca! ¡Día de tinieblas y de oscuridad, día de nublada y densa niebla!" (J1 2,1-2). El día de Yahvé, cuando supuestamente venga para dar la victoria a su pueblo contra sus enemigos, sucederá lo contrario. Dios vendrá a juzgar a Israel por sus perversiones y maldades. En ese día, Dios no luchara a favor, sino en contra de Israel.

Otra manera de manipular a Dios es recordarle continuamente la elección de Israel y, en consecuencia, de reclamarle su favor. El reclamo está expresado con claridad en la fórmula utilizada con frecuencia: "ya que nos has elegido, tenemos derecho a ser favorecidos por ti y estamos por encima de todos los pueblos". Pero los profetas no piensan de la misma manera. Para ellos, la elección significa amor apasionado, muy intenso, de Dios a su pueblo, pero no amor exclusivo. Por tanto, la elección y el amor no son un privilegio, tal como piensa la mayoría, sino una 
responsabilidad, de la cual Dios les podía pedir cuentas. Amós lo formula de la manera siguiente.

Yo había destruido al amorreo delante de ellos, que era alto como la altura de los cedros y fuerte como las encinas; yo había destruido su fruto por arriba y sus raíces por abajo. Y yo los hice subir a ustedes del país de Egipto y los llevé por el desierto cuarenta años, para que poseyeran la tierra del amorreo. Yo suscité profetas entre sus hijos, y nazireos entre sus jóvenes (Am 2,9-11).

Amós pronuncia estas palabras después de denunciar y amenazar al pueblo por sus muchas acciones perversas. Luego, continúa diciendo: "Así como yo me di a conocer a ustedes de un modo especialísimo de entre todas las naciones de la tierra, así también les pediré cuentas de un modo especial por su mala respuesta" (Am 3,2). Dios parece asumir aquí una frase que los israelitas repiten constantemente para afirmar su privilegio y su exclusividad. Pues Él se les habría dado a conocer de modo especialísimo y los habría elegido de entre todas las naciones. De esa manera, manipulan la elección divina. Amós concluye que si esto fuese verdadero, también lo sería que Dios tiene más derecho de pedirles cuentas, ya que no han sabido responder (ver Am 3,2).

En todo caso, Amós no parece estar de acuerdo con el presupuesto anterior, el de la elección exclusiva de Israel, entendida como privilegio. Por eso, desmitifica esa creencia. "Hijos de Israel, ¿no son ustedes para mí iguales que los etíopes?, dice el Señor. ¿No hice subir a Israel del país de Egipto, como también a los filisteos de Caftor [¿Creta?] y a los arameos de Quir [¿ciudad de Moab?]?" (9,7). Según este texto, el amor de Dios no se limita a un pueblo, sino que también conduce amorosamente a otros pueblos, como los arameos y los filisteos. Es decir, el amor de Dios no es exclusivo, sino incluyente.

El templo y el culto también son utilizados para manipular a Dios. El pueblo intenta convertir el templo en la prisión de Dios y los actos de culto en mecanismos de presión y coacción. Israel y Judá creen que la posesión del templo y la realización del culto les garantizan la salvación. Así, pues, gracias a ellos pueden arrebatar a Dios la salvación. Pero los profetas los desengañan. La presencia de Dios en medio de su pueblo depende de que este no oprima, no mate, no robe, y de que muestre la misericordia de Dios con los pobres, las viudas y los huérfanos.

Amós es el primero de los profetas en poner el dedo es esta llaga de manipular a Dios a través del culto en los santuarios. El texto siguiente comienza de manera irónica.

¡Vayan a Betel a rebelarse, multipliquen en Guilgal sus rebeldías, lleven por la mañana sus sacrificios y cada tres días sus diezmos; quemen levadura en acción de gracias y anuncien a los cuatro vientos ofrendas voluntarias, ya que es eso lo que les gusta a ustedes, hijos de Israel! 
A continuación, exhorta a buscar a Dios y a obrar de acuerdo con su voluntad, pues solo así se puede vivir realmente.

¡Búsquenme a mí y vivirán! Pero no me busquen en Betel, no vayan a Guilgal [...], porque Guilgal será deportada sin remedio y Betel será reducida a la nada. ¡Busquen a Yahvé y vivirán!

Busquen el bien, no el mal, para que vivan y esté así con ustedes Yahvé Sebaot, tal como andan diciendo ustedes por ahí. Aborrezcan el mal, amen el bien, implanten la justicia en los tribunales; quizás entonces Yahvé Sebaot tenga piedad del Resto de José (Am 4,4-5; 5-46.14-15).

La denuncia radical de Amós llega hasta el extremo de decir que los sacrificios y los diferentes actos de culto cansan a Dios. Él no es el origen de tales sacrificios, puesto que nunca los pidió en el desierto.

Yo odio sus fiestas, no me gusta el olor de sus reuniones solemnes. Si me ofrecen holocaustos, no me complazco en sus ofrendas ni pongo atención a sus sacrificios de comunión [...] iAparta de mi lado la multitud de tus canciones, no quiero oír tus arpas! ¿Que fluya, sí, el juicio como agua y la justicia como arroyo inagotable! ¿Acaso yo les pedí a ustedes que me ofrecieran sacrificios y oblaciones en el desierto, durante cuarenta años, casa de Israel? (Am 5,21-25).

Palabras parecidas pronuncian otros profetas, que insisten en que Dios está cansado de tanto engaño e hipocresía, y, en consecuencia, amenazan con la desaparición de todo ello. Así, Isaías exclama: "¡ya no soporto más sacrificios ni fiestas! [...] Cuando extienden sus manos para orar, me tapo los ojos para no verlos [...], porque hay sangre en sus manos" (Is 1,11-15). Miqueas cuestiona: “¿aceptará Yahvé los miles de carneros [...]?, ¿o será necesario que sacrifique a mi hijo mayor para pagar mi culpa?" (Mi 6,6-7). Jeremías insiste: "¿Qué me importa a mí el incienso importado de Saba [...]? Ya no me gustan los holocaustos, que ustedes hacen, y sus sacrificios me caen mal" (Jr 6,20).

No confíen en palabras mentirosas como estas: ¡Templo de Yahvé!, ¡templo de Yahvé!, ¡templo de Yahvé! [...] Dejen de oprimir al emigrante, al huérfano y a la viuda. No manchen este lugar con sangre de gente asesinada. No vayan en pos de otros dioses [...] Pero ustedes se fían de palabras engañosas [...] Ustedes roban, matan [...] Y dicen: "¡Aquí estamos seguros!” [...] ¿Se creen poder arrebatar así la salvación a Dios? Lo que les mandé, más bien, fue esto: "[...] Caminen por el camino que les indiqué" (Jr 7).

Tanto Miqueas, hacia el año 700 a. C., como Sofonías, hacia el año 630 a. C., y Jeremías, hacia el año 600 a. C., afirman que esa idolatría, unida a la mentira, la opresión, la violencia y la injusticia, llevarán a la destrucción no solo del templo, sino también de Jerusalén y de su parte más sagrada: Sion. Entonces, 
parecerá que Dios ha maldecido a la ciudad y su templo. En efecto, Miqueas advierte que "precisamente por sus maldades, Sion va a quedar como un potrero arado, Jerusalén será reducida a escombros y el cerro del templo será cubierto por el bosque" (Mi 3,12). En esa misma línea, Sofonías anuncia:

¡Ay de la rebelde, [...] la ciudad opresora! No ha escuchado la voz, [...] en Yahvé no ha puesto su confianza, a su Dios no se ha acercado. Sus príncipes [...] son leones rugientes; sus jueces, lobos de la tarde, que no dejan un hueso para la mañana; sus profetas, fanfarrones, hombres traicioneros; sus sacerdotes profanan lo que es santo y violan la Ley. Yahvé es justo [...] no comete injusticia [...] Y me dije: "Si al menos tú me respetaras [...]". Pero ellos, al contrario, se han apresurado a comportarse mucho peor. Por eso, espérenme, les dice Yahvé, para el día en que yo venga a acusarlos; cuando ordene [...] que se reúnan las naciones [...] para descargar sobre ustedes mi enojo [...], entonces todo el territorio será consumido por el fuego de mis celos (So 3,1-8).

Jeremías llama a la conversión: "Mejoren de conducta [...] y yo haré que se queden en este lugar [...] Porque si mejoran su conducta [...] si realmente hacen justicia mutua y no oprimen al inmigrante, al huérfano y a la viuda [...] entonces yo me quedaré con ustedes en este lugar. [...] Pero..." (7,3-8) "trataré esta casa mía como traté el santuario de Silo, y pondré a Jerusalén como ejemplo: todas las ciudades reconocerán que yo la maldije" $(26,6)$. "Pues así habla Yahvé [...]: 'Corten árboles y construyan un terraplén frente a Jerusalén, que es una ciudad mentirosa y que oprime [...], brota de ella la maldad [...] solo se oye hablar de violencia e injusticia"" $(6,6-7)$.

En la época del post-exilio, la fe en Yahvé corre un grave peligro. La búsqueda de signos de identidad lleva al pueblo judío a centrarse en su religión. En concreto, en una serie de actos externos - la circuncisión, la oración, el ayuno, la limosna, etc.-, que convierte en referentes de su identidad. Incluso llega a pensar que estos actos son garantía de identidad judía y, por tanto, obligaban a Dios a bendecirlos y a darles la felicidad. De esa manera, esos signos se vuelven otros modos de manipular a Dios.

De nuevo, los profetas ponen al descubierto la trampa en que colocan la relación del pueblo con Dios. No se trata de cumplir con prácticas piadosas como muestra de gran interés por agradar a Dios, sino de la vida diaria, donde se comportan de manera inhumana, irrespetuosa e injusta con el prójimo. Dios repudia esa conducta. En el Tercer Isaías encontramos un texto muy significativo.

Dicen que me buscan día a día y que les agrada conocer mis caminos, como si fueran gente que practica la virtud y se relaciona con Dios. Parecen interesados por las leyes justas y por mi cercanía; y me preguntan: "¿Por qué ayunamos, si tú no lo ves? ¿Para qué nos humillamos, si tú no lo sabes?". Y yo les respondo: "Porque el día en que ayunan, buscan su propio provecho y 
explotan a todos sus trabajadores. En realidad, ayunan en medio de peleas y pleitos, y golpean con maldad. No es esta clase de ayunos la que logrará que sus voces sean escuchadas en lo alto. ¿Acaso es este el ayuno que yo quiero el día en que se humilla el hombre? ¿Doblegar como junco la cabeza, estarse echado en sayal y ceniza? ¿A eso llaman ayuno y día grato a Yahvé?” (Is 58,5-8).

\subsection{La divinización idolátrica del poder}

Los profetas reaccionan a la divinización del poder y a la búsqueda de los propios intereses, por encima de cualquier otra cosa, con una sensibilidad muy particular. Ambas tendencias producen nuevas esclavitudes, en concreto, para los excluidos y desprotegidos. Frente a ello, los profetas anuncian que la autoridad debe estar al servicio de la libertad, la vida digna y la paz del pueblo. En consecuencia, no deben causar extrañeza las muchas denuncias de Amós, Isaías y Miqueas contra los reyes, los gobernantes, los jueces, etc. Incluso Oseas se atreve a decir que Dios comienza a odiar a Israel en Guilgal, donde se puso de manifiesto toda su maldad. Por tanto, ya no los amará y los expulsará. La referencia a Guilgal remite al origen de la monarquía, que para Oseas es como el pecado original de Israel (ver Os 9,15).

Centrémonos en algunos textos importantes de Isaías, Jeremías y Ezequiel que hablan de los reyes y pastores. En los siguientes textos, Isaías relaciona al rey ungido por Dios con el trabajo por la justicia y la paz.

Grande es su señorío y la paz no tendrá fin sobre el trono de David y sobre su reino, para restaurarlo y consolidarlo por la equidad y la justicia, desde ahora y para siempre. El celo de Yahvé piensa hacer efectivo todo esto (Is 9,6).

De las raíces del tronco de Jesé brotará una ramita [...] No juzgará por las apariencias ni sentenciará de oídas. Juzgará con justicia a los débiles, con rectitud a los pobres de la tierra. Herirá al hombre cruel con la vara de su boca, con el soplo de sus labios acabará con el malvado. Justicia será el cincho de su cintura, verdad el cinturón de sus lomos. Serán vecinos el lobo y el cordero, y el leopardo se echará con el cabrito, el novillo y el cachorro de león pacerán juntos, y un niño pequeño los pastoreará. La vaca y la osa pacerán una al lado de la otra, juntas acostarán sus crías. El león, como los bueyes, comerá paja. Hurgará el niño de pecho en el agujero del áspid, y en el nido de la víbora el recién destetado meterá la mano. Nadie hará daño, nadie hará mal [...] porque la tierra estará llena de una profunda relación con Yahvé, como cubren las aguas el mar (Is 11,1-9).

Jeremías es más explícito: "Casa de David, esto dice Yahvé: Hagan justicia cada mañana, salven al oprimido de la mano del opresor, no sea que mi cólera brote como el fuego y arda y no haya quien la apague, a causa de las malas acciones de ustedes" (Jr 21,11-12). 
Oye la palabra de Yahvé, tú, rey de Judá, que ocupas el trono de David, y tus servidores y pueblo [...] Practiquen el derecho y la justicia; libren al oprimido de manos del opresor; no atropellen al inmigrante, al huérfano y a la viuda; no hagan violencia ni derramen sangre inocente en este lugar. Porque si ponen en práctica esta palabra, entonces seguirán entrando por las puertas de esta casa reyes sucesores de David [...] Si no... (Jr 22,1-5).

En estos textos, Jeremías señala las tareas de los reyes y condiciona su permanencia en el trono a su cumplimiento, en concreto, a la promoción de la justicia, la liberación y la solidaridad. Enseguida, el profeta denuncia a Joaquín I por obrar injusta e ilegalmente, por no pagar el salario debido, por edificar construcciones lujosas e innecesarias, por oprimir a sus súbditos, por derramar sangre inocente. En una palabra, por no haber sido como su padre, el rey Josías, que sí había sido justo y se había ocupado del pobre y del excluido.

¡Ay del que edifica su casa sin justicia y sus pisos sin derecho! De su prójimo se sirve de balde y su trabajo no le paga. El que dice: "Voy a edificarme una casa espaciosa y pisos ventilados", y le abre sus correspondientes ventanas; pone paneles de cedro y los pinta de rojo. ¿Serás acaso rey porque seas un apasionado de las construcciones lujosas? Tu padre ¿no comía y bebía? Pero también hizo justicia y equidad. Y le fue bien. Y juzgó la causa del humilde y el pobre. Y le fue todavía mejor. Pues, ¿no es esto relacionarse profundamente conmigo? - oráculo de Yahvé. Pero tus ojos y tu corazón no están más que a tu ganancia traficando. $¡ Y$ al derramamiento de sangre inocente! $¡ Y$ al atropello y al engaño! [...] Por tanto, así dice Yahvé respecto a Joaquín I [...]: No lo llorarán “¡Ay, hermano mío!, jay, hermana mía!”; no se lamentarán por su muerte “¡Ay, Señor!, ¡ay, su Majestad!”. El entierro de un borrico será el suyo [...] fuera de las murallas de Jerusalén (Jr 22,13-19).

Jeremías concluye su colección de dichos sobre los reyes, su tarea y su realidad, con un texto sobre los pastores irresponsables. Es una denuncia de las autoridades, que no han sabido mantener al pueblo unido y en paz. Asimismo, anuncia que Dios mismo reunirá a las ovejas dispersas y las hará vivir en paz, cuidadas por nuevos pastores.

¡Ay de los pastores que dejan perderse y desparramarse las ovejas de mis pastos! [...] Esto dice Yahvé [...] sobre los pastores que apacientan a mi pueblo: Ustedes han dispersado mis ovejas, las han empujado y no se han cuidado de ellas. Pues bien, voy a pedirles cuentas por sus malas obras [...] Yo recogeré el Resto de mis ovejas de todas las tierras a donde las dispersé, las haré tornar a sus pastos, criarán y se multiplicarán. Y pondré al frente de ellas pastores que las apacienten, y nunca más estarán medrosas ni asustadas, ni faltará ninguna [...] Miren que vienen días en que suscitaré a David un Germen justo: reinará un rey prudente, practicará el derecho y la justicia en la 
tierra. En sus días estará a salvo Judá, e Israel vivirá en seguro. Y a este rey lo llamarán: "Yahvé, justicia [salvación] para todos nosotros" (Jr 23,1-6).

En Ezequiel 34 y 36, encontramos un desarrollo de este texto de Jeremías. En esos capítulos, el profeta pronuncia palabras de esperanza, en unos momentos donde no hay razones para esperar. El texto comienza con una fuerte denuncia contra los pastores que se apacientan a sí mismos y no se ocupan de las ovejas. Más bien se aprovechan de ellas, sin importarles cómo se encuentran, sin defenderlas de los peligros que las acechan y sin guardarlas en sitio seguro y en paz.

La palabra de Yahvé se dirigió a mí en estos términos: Hijo de hombre, profetiza contra los pastores de Israel [...]: ;Ay de los pastores de Israel que se apacientan a sí mismos! ¿No deben los pastores apacentar el rebaño? Ustedes se han tomado la leche, se han vestido con la lana, han sacrificado las ovejas más pingües; no han apacentado el rebaño. No han fortalecido a las ovejas débiles, no han cuidado a la enferma ni curado a la que estaba herida, no han tornado a la descarriada ni buscado a la perdida; sino que las han dominado con violencia y dureza. Y ellas se han dispersado, por falta de pastor, y se han convertido en presa de todas las fieras del campo; andan dispersas. Mi rebaño anda errante por todos los montes [...], disperso por toda la superficie de la tierra, sin que nadie se ocupe de él ni salga en su busca. Por eso, pastores, escuchad la palabra de Yahvé: Por mi vida, oráculo del Señor Yahvé, lo juro: Porque mi rebaño ha sido expuesto al pillaje y se ha hecho pasto de todas las fieras del campo por falta de pastor, porque mis pastores no se ocupan de mi rebaño, porque ellos, los pastores, se apacientan a sí mismos y no apacientan mi rebaño; por eso, pastores, escuchen la palabra de Yahvé: [...] Aquí estoy yo contra los pastores: reclamaré mi rebaño de sus manos y les quitaré de apacentar mi rebaño. Así los pastores no volverán a apacentarse a sí mismos. Yo arrancaré mis ovejas de su boca, y no serán más su presa (Ez 34,1-10).

A continuación, Dios anuncia que él mismo velará por las ovejas. Las reunirá de nuevo, las curará cuando estén heridas, preferirá a aquellas que hayan sido maltratadas por otras y se pondrá siempre de su parte.

Porque así dice el Señor Yahvé: Aquí estoy yo; yo mismo [...] velaré por mi rebaño. Como un pastor vela por su rebaño cuando se encuentra en medio de sus ovejas dispersas, así velaré yo por mis ovejas. Las recobraré de todos los lugares donde se habían dispersado en día de nubes y brumas. Las sacaré de en medio de los pueblos, las reuniré de los países, y las llevaré de nuevo a su suelo. Las pastorearé por los montes de Israel, por los barrancos y por todos los poblados de esta tierra. Las apacentaré en buenos pastos [...] Allí reposarán [...] y pacerán pastos abundantes [...] Yo mismo apacentaré mis ovejas y yo las llevaré a reposar [...] Buscaré la oveja perdida, tornaré a la descarriada, curaré a la herida, confortaré a la enferma; pero a la que está gorda y robusta la exterminaré; las pastorearé con justicia (Ez 34,11-16). 
A continuación, Ezequiel concreta en qué consiste tomar partido. El Señor se constituirá en juez entre oveja y oveja. Entre aquellas que, por ser más fuertes y poderosas, maltratan y oprimen a las otras, y aquellas otras que, por ser débiles y pequeñas, son oprimidas y encuentran dificultades para salir airosas adelante.

[...] yo voy a juzgar entre oveja y oveja, entre carnero y macho cabrío. ¿Les parece poco pacer en buenos pastos, para que pisoteen con los pies el resto de los pastos? ¿Les parece poco beber en agua limpia, para que enturbien el resto con los pies? ¡Mis ovejas tienen que pastar lo que los pies de ustedes han pisoteado y beber lo que los pies de ustedes han enturbiado! Por eso, así les dice el Señor Yahvé: Yo mismo voy a juzgar entre la oveja gorda y la flaca. Puesto que ustedes han empujado con el flanco y con el lomo y han topado con los cuernos a todas las ovejas más débiles hasta dispersarlas fuera, yo vendré a salvar a mis ovejas para que no estén más expuestas al pillaje; voy a juzgar entre oveja y oveja (Ez 34,12-21).

Ezequiel concluye su discurso sobre los pastores afirmando que Dios se compromete a enviar un pastor nuevo y bueno, que cuidará a sus ovejas e inaugurará una alianza de paz, la cual desembocará en una nueva situación paradisíaca, donde todo será paz, abundancia y felicidad.

Yo suscitaré para ponérselo al frente un solo pastor que las apacentará, mi siervo David: él las apacentará y será su pastor. Yo, Yahvé, seré su Dios, y mi siervo David será príncipe en medio de ellos. Yo, Yahvé, he hablado. Concluiré con ellos una alianza de paz, haré desaparecer de esta tierra las bestias feroces. Habitarán en seguridad en el desierto y dormirán en los bosques. Yo los asentaré en los alrededores de mi colina, y mandaré a su tiempo la lluvia, que será una lluvia de bendición. El árbol del campo dará su fruto, la tierra dará sus productos, y ellos vivirán en seguridad en su suelo. Y sabrán que yo soy Yahvé, cuando despedace las barras de su yugo y los libre de la mano de los que los tienen esclavizados. No volverán a ser presa de las naciones, las bestias salvajes no volverán a devorarlos. Habitarán en seguridad y no se les turbará más. Haré brotar para ellos un plantío famoso; no habrá más víctimas del hambre en el país, ni sufrirán más el ultraje de las naciones. Y sabrán que yo, Yahvé su Dios, estoy con ellos, y que ellos, la casa de Israel, son mi pueblo, oráculo del Señor Yahvé. Ustedes, ovejas mías, son el rebaño humano que yo apaciento, y yo soy su Dios, oráculo del Señor Yahvé (Ez 34,12-31).

Sin embargo, el profeta está convencido de que esta acción de Dios, más relacionada con la estructura del poder, será complementada por otra, dirigida al interior de las personas. Sin ella, no puede haber auténtico cambio social. Dios purificará a su pueblo y, sobre todo, le quitará el corazón de piedra y le dará uno de carne, capaz de solidaridad, de compasión y de misericordia. Cuando esto suceda, volverá a ser su pueblo y él será su Dios. En consecuencia, la gloria 
de Dios volverá a resplandecer, pues, como dice Proverbios 14,31 (ver Pr 17,5), "quien oprime al pobre, ultraja a su creador, quien se compadece del excluido, le da gloria [a Dios]".

Así dice el Señor Yahvé: No hago esto por consideración a ustedes, casa de Israel, sino por mi santo nombre, que ustedes han profanado entre las naciones adonde fueron. Yo santificaré mi gran nombre profanado entre las naciones [...]. Y las naciones sabrán que yo soy Yahvé [...] cuando yo, por medio de ustedes, manifieste mi santidad a la vista de ellos. Los tomaré de entre las naciones, los recogeré de todos los países y los llevaré a su suelo. Los rociaré con agua pura y quedaréis purificados [...] Y les daré un corazón nuevo, infundiré en ustedes un espíritu nuevo, quitaré de su carne el corazón de piedra y les daré un corazón de carne. Infundiré mi espíritu en ustedes y haré que vivan según mi voluntad [...] Habitarán la tierra que yo di a sus padres. Ustedes serán mi pueblo y yo seré su Dios (Ez 36,22-28).

\subsection{La injusticia social o la ruptura de la fraternidad}

Simultáneamente con lo anterior, el pueblo de Dios rompe su fraternidad y se comienzan a dar situaciones de auténtica desigualdad, de injusticia social, de marginación, de empobrecimiento y de muerte lenta o violenta, ya que los críticos son reprimidos. La sociedad que emerge es, así, totalmente extraña al éxodo. Es una sociedad donde algunos adoran a la riqueza, mientras la mayoría se empobrece. Los profetas analizan, juzgan y denuncian esta realidad y llaman al cambio o a la conversión desde Dios. Estos llamados les acarrean persecución y muerte.

Uno de los problemas sociales más graves nace de la ambición desmesurada por poseer y acaparar toda clase de bienes. La acumulación produce creciente desigualdad, entre los que poseen mucho, por no decir casi todo, y la mayoría que se reparte lo poco que queda. En esas condiciones, resulta muy difícil vivir con dignidad. Los profetas denuncian con mucha fuerza este hecho social, porque es lo más contrario a la experiencia liberadora que había dado origen al pueblo. Veamos algunos ejemplos de esta denuncia.

¡Ay de ustedes que juntan casa con casa y campo a campo anexionan, hasta ocupar todo el territorio y quedarse solos en medio del país! Así ha jurado a mis oídos Yahvé Sebaot: “iQuedarán desiertas muchas casas grandes y hermosas; nadie las habitará! Diez cuadras de viña apenas darán un barril de vino y una carga de semilla solo producirá un puñado" (Is 5,8-10).

¡Ay de quienes planean injusticias, se pasan la noche tramando maldades y cuando amanece las hacen realidad, pues tienen el poder en sus manos! Si les gustan campos, los roban; si casas, las roban; se apoderan del hombre y de toda su casa, de la persona y de su heredad. [...] Son ustedes los enemigos 
de mi pueblo, pues le quitan su manto al inocente y tratan como a su enemigo a quien no les ha hecho nada en contra. Arrancan de sus hogares queridos a las mujeres de mi pueblo y les quitan a sus niños la libertad que yo les había dado (Mi 2,1-2.8-9).

Otro de los grandes problemas, que contribuye a la desigualdad y la injusticia, es que los ricos y los poderosos se niegan a renunciar a sus lujos. Así, viven de espaldas a la dura realidad que hace sufrir a los pequeños. Por eso, los profetas denuncian su actitud. Amós, en concreto, proclama: "Escuchen esta palabra, vacas de Basán, que viven en la parte alta de la ciudad de Samaria, que oprimen a los débiles, que maltratan a los pobres, que dicen a sus maridos: '¡Traigan vino y bebámoslo!"” $(4,1)$.

¡Ustedes tratan de alejar el día de su desgracia, y hacen que se acerque un estado de violencia! Acostados en camas de marfil, arrellanados en sus sofás, comen corderitos del rebaño y terneros sacados del establo, canturrean al son del arpa, se inventan, como David, instrumentos de música, beben vino en grandes copas, con los mejores aceites se ungen, pero no se afligen por el desastre de José (Am 6,3-6).

Yahvé dice: Muy altivas caminan las señoronas de Sion, con el cuello estirado y la mirada provocativa, y caminan a pasitos cortos haciendo sonar los cascabeles de sus pies. Por eso, el Señor llenará de sarna sus cabezas y quedarán pelonas; y además, las dejará desnudas. Aquel día quitará el Señor el adorno de las ajorcas, los solecillos y las lunetas; los aljófares, las lentejuelas y los cascabeles; los peinados, las cadenillas de los pies, los ceñidores, los pomos de olor y los amuletos, los anillos y aretes de nariz; los vestidos preciosos, los mantos, los chales, los bolsos, los espejos, las ropas finas, los turbantes y las mantillas. En lugar de sus perfumes habrá mal olor, en lugar de un cinturón una soga, en lugar de cabello trenzado cabeza rapada, en lugar de vestidos lujosos tela de costal y en lugar de belleza una marca hecha con hierro al rojo [como los animales marcados] (Is 3,16-24).

¡Ay de quienes son campeones en beber vino, los valientes para mezclar licores, los que absuelven al malo por soborno y quitan al inocente su derecho (Is 5,22-23).

En estas circunstancias, las relaciones fraternales, queridas por Dios, inevitablemente se rompen. La mentira y el engaño son prácticas comunes. La ausencia de verdad llena de amargura a los pobres, a quienes nadie daba la razón, aun cuando la tuvieran.

¡Ay de los que esconden con engaños la culpa y el pecado que han cometido [hipócritas] y que para colmo retan al Señor diciendo: “iListo, que apresure su acción, para que la veamos! ¡Que se acerque y realice su plan para que lo conozcamos!" (Is 5,18-19). 
iAy de quienes llaman al mal bien y al bien mal, que ofrecen oscuridad en lugar de luz y luz en lugar de oscuridad, que dan amargo por dulce y dulce por amargo! (Is 5,20).

Probablemente, el último texto se refiere a los jueces y a los tribunales, que con sus sentencias endulzan o amargan la vida de la gente.

El fraude comercial es otro problema grave. En los primeros tiempos, el comercio opera mediante el canje de bienes, es decir, en los intercambios no se usa la moneda. Tampoco se necesitan pesos y medidas para establecer las equivalencias de los bienes intercambiados. Pero cuando se introducen la moneda y los pesos y las medidas, resultan perjudicados los campesinos, que, por su poca cultura, se equivocan o son engañados fácilmente. Los profetas son muy sensibles a esta situación de injusticia.

Escuchen esto los que explotan al pobre y quieren suprimir a los humildes de la tierra, diciendo: ¿Cuándo pasará la fiesta de la luna nueva y la celebración del sábado para poder comerciar y vender el trigo, para achicar la medida y aumentar el peso, falsificando balanzas de fraude, para vender por dinero a los débiles y a los pobres por un par de sandalias, para vender con fraude incluso la paja del grano? (Am 8,4-6).

Yahvé grita a la ciudad: ¡Escuchen, pueblo y sus gobernantes! ¿He de soportar yo una medida falsa y unos pesos disminuidos [...]? ¿Tendré por justa la balanza falseada y la bolsa de pesas fraudulentas? ¡Sus ricos se enriquecen cometiendo crímenes y sus habitantes mienten de tal manera que su lengua solo pronuncia falsedades! (Mi 6,9-12).

La violencia es causa y consecuencia de los problemas anteriores. Los profetas son testigos de cómo un pueblo surgido de la esclavitud, para llevar una vida digna, es víctima de los gobernantes y los poderosos. Dios no había liberado al pueblo de la esclavitud para someterlo a la injusticia y la violencia. Su plan era un pueblo alternativo, cuyas relaciones no se fundaran en la fuerza y la violencia.

Pregonen en los palacios de Asur, y en los palacios del país de Egipto; digan: ¡Congréguense contra los montes de Samaria, y vean cuántos desórdenes en ella, cuántos crímenes en ella se cometen! No saben obrar con rectitud [...] los que amontonan violencia y rapiña en sus palacios [...] Destruiré la casa de invierno y la casa de verano, desaparecerán las casas de marfil, y muchas casas serán demolidas (Am 3,9-10.15).

Mira tus manos manchadas de sangre, no de bandidos sorprendidos en un acto criminal, sino que de inocentes $\left(\mathrm{J}_{\mathrm{r}} 2,34\right)$.

La gente del país comete violencia y se entrega al pillaje, pisotea al pobre, maltrata al indigente y oprime al inmigrante sin razón alguna (Ez 22,29). 
La ley no protege a los más débiles, sino que los deja indefensos a merced de la ambición del poderoso. Esto resulta insoportable para un Dios que se había dado a conocer, precisamente, en la defensa de los más pequeños.

¡Ay de quienes legislan leyes injustas y con sus decretos convierten en legal la opresión, impidiendo que la justicia llegue a los pobres, violando los derechos de los míseros de mi pueblo, convirtiendo a las viudas en su botín y despojando de todo a los huérfanos (Is 10,1-2).

De esta manera, los responsables del bienestar del pueblo y los poderosos oprimen a los débiles y los pobres. $Y$ lo hacen despreocupadamente, sin importarles la muerte lenta o rápida causada por sus acciones.

Así dice Yahvé: ¡Por tres crímenes de Israel y por cuatro, seré inflexible! Porque venden al justo por dinero y al pobre por un par de sandalias; pisan contra el polvo de la tierra la cabeza de los débiles, y la vida de los humildes retuercen; hijo y padre acuden a la misma joven de servicio, para profanar mi santo Nombre; sobre ropas empeñadas se acuestan junto a cualquier altar, y el vino de los que han multado beben en la casa de su dios (Am 2,6-8).

Yahvé demanda ante la justicia a los ancianos de su pueblo y a sus jefes. Ustedes han devorado los frutos de mi viña, en sus casas están los despojos del mísero. ¿Con qué derecho oprimen a mi pueblo y ponen sus pies sobre el rostro de los pobres? (Is 3,14-15; cfr. Ez 34,17-22).

Los poderosos se protegen entre ellos y se confabulan para extraer más beneficios del pobre y del indefenso. El colmo es que se presentan como personas religiosas, dispuestas a apoyar su religión. De esa manera, la justicia está al servicio de los poderosos, mientras los pobres se sumen en la amargura. “¿Galopan por la roca los caballos?, ¿se ara con bueyes el mar? ¡Pues ustedes [los jueces] cambian en veneno la justicia y en algo amargo las sentencias judiciales!" (Am 6,12; cfr. 2,6-8).

¡Cómo se ha hecho adúltera la villa fiel! Sion estaba llena y albergaba la equidad y la justicia; ahora, sin embargo, no hay más que asesinos en ella. Tu plata se ha convertido en escoria. Tu vino está mezclado con agua. Tus jefes son rebeldes y aliados de ladrones. Cada cual ama el soborno y va tras los regalos. No hacen justicia al huérfano y no atienden al pleito de la viuda (Is 1,21-23).

Escuchen, gobernantes [...]: ¿No deberían ustedes amar la justicia, ustedes que en realidad odian el bien y aman el mal, que le arrancan la piel a mi pueblo y la carne de sobre sus huesos? Quienes han comido la carne de mi pueblo, quitado su piel, quebrado sus huesos y lo han despedazado como carne en la caldera, como vianda dentro de una olla (Mi 3,1-3). 
[Ustedes,] que desprecian la justicia y tuercen todo lo que es recto, que edifican a Sion con sangre y a Jerusalén con maldad. Sus jefes se dejan comprar para dar una sentencia, sus sacerdotes enseñan por salario, sus profetas vaticinan por dinero, y para colmo se hacen pasar por amigos de Yahvé y dicen: ¿No está Yahvé en medio de nosotros? ¡No nos puede venir sobre nosotros ningún mal! (Mi 3,9-11).

¡Ay de mí, que he venido a ser como quienes van a pepenar espigas después de la siega o racimos de uva después de la vendimia! ¡No he encontrado ni un racimito para probarlo ni una de esas primeras brevas que tanto me gustan! ¡Ya no existen personas fieles y justas! Todas las personas acechan en busca de sangre, cada cual atrapa en la red a su hermano. Sus manos son buenas para hacer el mal: el gobernante y el juez exigen recompensa por sus servicios, el poderoso decide según le conviene (Mi 7,1-3).

Sucederá [...] que yo castigaré a los ministros, a los hijos del rey y a todos los que visten a la moda extranjera. Les daré también su merecido a quienes están en los círculos del poder (a todos los que saltan por encima del umbral), los que llevan a la casa de su señor el producto de sus crímenes y robos (So 1,8-9).

¡A la casa de David! Así dice Yahvé: Hagan justicia cada mañana, y salven al oprimido de mano del opresor, so pena de que brote como fuego mi cólera y arda y no haya quien apague, a causa de sus malas acciones (Jr 21,12).

Escucha, rey, a Yahvé: Practiquen la justicia y hagan el bien; libren de la mano del opresor al que ha sido despojado; no maltraten al inmigrante, ni al huérfano ni a la viuda; no les hagan violencia, ni derramen sangre inocente en este lugar.

$$
\text { [...] }
$$

¡Ay del que construye su casa a base de robos y edifica sus pisos a base de sus injusticias! ¡Ay de aquel que se aprovecha de su prójimo y lo hace trabajar sin pagarle su salario! De su prójimo se sirve de balde y su trabajo no le paga. El que dice: Me voy a construir un palacio inmenso, con pisos espaciosos, y luego voy a abrir sus correspondientes ventanas y las cubriré con madera de cedro, toda pintada de rojo. ¿Acaso serás más rey por tener más cedro? A tu padre, ¿acaso le faltó comida y bebida? Sin embargo, él se preocupaba de la justicia y del derecho, y todo le iba bien. Además, él juzgaba la causa del desamparado y del pobre, y todo le iba mejor. Pues bien, Yahvé ahora te pregunta: Conocerme, ¿no es actuar de esta forma? Pero tú solo piensas en tu interés, en derramar sangre y mantener la opresión y la violencia. Eso sí que te gusta (Jr 22,1-3.13-17). 


\subsection{Israel se cierra a los demás pueblos}

El proyecto de Dios está abierto a la salvación de las naciones, mediante el testimonio de Israel. Pero este perdió el horizonte. El pueblo de Dios dejó de ser el pueblo testimonial querido por Dios, sobre todo, a partir de la experiencia del exilio. Entonces, Israel cae en la tentación de impulsar una restauración fundamentada en unas prácticas de identidad que tienden a cerrarlo cada vez más a los otros pueblos. Además, abandona la perspectiva de construir un modo de vida alternativo, que fuera en sí mismo testimonio de cómo es posible vivir de otra manera. Muchos profetas de la restauración, como el Tercer Isaías, insisten en que el pueblo de Dios no puede encerrarse en sí mismo, sino que debe permanecer abierto a los otros pueblos para ser camino de salvación para ellos. Pero solo se puede dar testimonio, si se vive de esa manera alternativa, es decir, fraternal, a la cual Dios había llamado a su pueblo, al sacarlos del dominio egipcio.

Así dice Yahvé: Velen por la equidad y practiquen la justicia, que mi salvación está para llegar y mi justicia para manifestarse. Dichoso el mortal que tal haga, el hombre que persevere en ello, guardándose de profanar el sábado, guardando su mano de hacer nada malo.

Que el extranjero que se adhiera a Yahvé, no diga: ¡De cierto que Yahvé me separará de su pueblo! No diga el eunuco: Soy un árbol seco. Pues así dice Yahvé: Respecto a los eunucos que guardan mis sábados y eligen aquello que me agrada y se mantienen firmes en mi alianza, yo he de darles en mi Casa y en mis muros monumento y nombre mejor que hijos e hijas; nombre eterno les daré que no será borrado.

En cuanto a los extranjeros adheridos a Yahvé para su servicio, para amar el nombre de Yahvé, y para ser sus siervos, a todo aquel que guarda el sábado sin profanarle y a los que se mantienen firmes en mi alianza, yo les traeré a mi monte santo y les alegraré en mi Casa de oración. Sus holocaustos y sacrificios serán gratos sobre mi altar. Porque mi Casa será llamada Casa de oración para todos los pueblos (Is 56,1-7).

El libro didáctico de Jonás presenta a un "profeta" que se resiste a hablar a Nínive, porque no forma parte del pueblo de Dios. Pero este lo corrige y lo presiona para que finalmente hable a Nínive, con la esperanza de que se convierta y acepte a Dios. Este libro muestra que a Dios no le gusta la cerrazón de su pueblo, porque lo había llamado a dar testimonio universal. Así, pues, Dios quería y quiere la salvación de todos los pueblos.

Estas realidades de pecado no reflejan la experiencia fundante del pueblo de Israel, ni se ajustan al proyecto liberador de Dios. Al contrario, frustran sus planes y su voluntad. Las tradiciones proféticas insisten en que, a pesar del pecado, aún hay esperanza. Dios sigue adelante con su sueño y su proyecto liberador. 


\section{Las tradiciones proféticas: recuerdo constante del proyecto original}

Después de analizar cómo las tradiciones proféticas desenmascaran y denuncian las múltiples situaciones en las cuales el pueblo rompe con el proyecto liberador de Dios, conviene fijarnos en cómo esas mismas tradiciones recuerdan constantemente dicho proyecto original. Se trata, por tanto, de analizar cómo mira Dios el futuro de su pueblo y de la humanidad.

\subsection{Dios llama a una relación auténtica}

Dios llama a su pueblo y a la humanidad a establecer una relación auténtica con él, basada en la justicia, la misericordia y la solidaridad.

¡Busquen, en cambio, a Yahvé y vivirán, no sea que caiga él como fuego sobre la casa de José, y devore Betel, su santuario central, sin que haya quien apague! [...] Busquen el bien, no el mal, para que vivan, y que así sea con ustedes Yahvé Sebaot, tal como van diciendo siempre. Aborrezcan el mal, amen el bien, hagan justicia en los tribunales; quizá entonces Yahvé Sebaot tenga piedad del Resto de José (Am 5,6.14-15).

Yo te desposaré conmigo para siempre; te desposaré conmigo y las bases de nuestro matrimonio serán la justicia y el derecho, el amor y la compasión, te desposaré conmigo en fidelidad, y tú conocerás a Yahvé (Os 2,21-22).

Porque yo quiero amor, no sacrificios; relación profunda con Dios, más que holocaustos (Os 6,6).

Aprendan a hacer el bien, busquen lo justo, den sus derechos al oprimido, hagan justicia al huérfano, aboguen por la viuda (Is 1,17 ).

Se te ha declarado, hombre, lo que es bueno, lo que Yahvé de ti reclama: tan solo practicar la justicia, amar con misericordia y caminar día a día con tu Dios (Mi 6,8).

\subsection{Dios llama aun en la ruptura}

Aun cuando el pueblo y la humanidad han roto con Dios, este los sigue amando apasionadamente, incluso antes de que se conviertan. Oseas es el profeta que formula este principio con más claridad y con una enorme originalidad. Aunque Dios desea castigar a su pueblo por su actitud pecaminosa y su alejamiento, no tiene fuerzas para ello. Está al borde del infarto, porque su amor y su misericordia son mayores que su cólera. Por eso, decide seducirlo de nuevo, enamorarlo, llevarlo al desierto y desposarlo con la esperanza de que se convierta. Además de la imagen del esposo-esposa, el profeta utiliza la del padremadre y su dolorosa relación con una descendencia díscola, cuanto más amor le muestra, esta más se aleja. Pese a ello, los padres-Dios siguen buscándola con mayor amor y con la esperanza de atraerla de nuevo a su regazo. 
Por eso voy a seducirla; voy a llevarla al desierto y le hablaré al corazón. Allí le daré sus viñas, convertiré el valle de Acor en puerta de esperanza; y ella responderá allí como en los días de su juventud, como el día en que subía del país de Egipto. Y sucederá aquel día [...] que ella ya no me llamará "Baal mío", sino "Esposo mío", y conseguiré que ya no invoque más a los Baales. Aquel día sellaré en su favor un pacto con la bestia del campo, con el ave del cielo, con el reptil del suelo; romperé y alejaré de esta tierra arco, espada y guerra. Y a ellos los haré reposar en paz.

Yo te desposaré conmigo para siempre; te desposaré conmigo en justicia y en derecho, en amor y en compasión; te desposaré conmigo en fidelidad. Y volverás a relacionarte profundamente conmigo.

Y sucederá aquel día que yo responderé [...] a lo que los cielos esperan de mí, y ellos responderán a lo que la tierra espera de ellos; la tierra responderá a lo que esperan de ella el trigo, el mosto y el aceite virgen; y ellos responderán a lo que significa el nombre de Yizreel [Cosecha de Dios]. Y entonces, yo sembraré la tierra, me compadeceré de "no-compadecida" y diré a "no-mipueblo" tú eres "Mi pueblo", y él dirá "iMi Dios” (Os 2,16-25).

Cuando Israel era niño, lo amé, y de Egipto llamé a mi hijo. Pero cuanto más los llamaba, más se alejaban de mí [...].

Yo enseñé a caminar a Efraín, tomándole por los brazos, pero ellos no sabían que yo los cuidaba. Con cuerdas humanas y con lazos de amor, los atraía; yo era para ellos como quienes alzan a un niño contra su mejilla; me inclinaba hacia él y le daba de comer.

Volverá a Egipto y Asur será su rey, pues se han negado a convertirse. La espada los destruirá. ¡Qué triste! [...] Mi pueblo se ha acostumbrado a abandonarme y por eso cuando claman hacia lo alto, nadie los toma en brazos. Pero, ¿cómo voy a abandonarte, Efraín, cómo voy a soltarte, Israel? [...] Mi corazón está al borde del infarto y tengo retortijones en mis entrañas. No, no daré curso al furor de mi cólera, no volveré a destruir a Efraín, porque soy Dios, no hombre [...]; dejaré, por tanto, la ira a un lado y no me dejaré llevar por ella (Os 11,1-9).

Jeremías también utiliza las mismas imágenes para hablar de un Dios tan apasionado por su pueblo, que hará todo lo necesario para recuperarlo y enamorarlo.

Entonces, me dirigió Yahvé la palabra en estos términos: Ve y grita a los oídos de Jerusalén: Así dice Yahvé: De ti, recuerdo tu cariño juvenil, el amor de tu noviazgo; aquel seguirme tú por el desierto, por la tierra no sembrada. Consagrado a Yahvé estaba Israel, primicias de su cosecha. "Quienquiera que lo coma, será reo; mal le sucederá" - oráculo de Yahvé. 


\section{$[\ldots]$}

¿Se olvida una chica de su aderezo, o una novia de su cinta? Pues mi pueblo sí que me ha olvidado días sin cuento. ¡Qué hermoso ves tu camino en busca del amor! Y eso que hasta con maldades aprendiste tus caminos.

$$
\text { [...] }
$$

Pues bien. "Supongamos que despide un marido a su mujer; ella se va de su lado y es de otro hombre: ¿podrá volver a él?; ¿no sería como una tierra manchada?". Pues bien, tú has fornicado con muchos compañeros, iy vas a volver a mí! - oráculo de Yahvé.

$$
\text { [...] }
$$

Y aun entonces, ¿no me llamabas: "Padre mío, tú, el amigo de mi juventud?; ¿tendrá rencor para siempre?, ¿lo guardará hasta el fin?". Ahí tienes cómo has hablado; las maldades que hiciste las has colmado.

$$
\text { [...] }
$$

Yo había dicho: "Sí, te adoptaré por hijo y te daré una tierra espléndida, flor de las heredades de las naciones". Y añadí: "Padre me llamarán y de mi seguimiento no se volverán".

$$
\text { [...] }
$$

Vuelvan, hijos apóstatas; yo remediaré sus apostasías. "Aquí nos tienes de vuelta a ti, porque tú, Yahvé, eres nuestro Dios".

$$
\text { [...] }
$$

¡Si vuelves, Israel!, oráculo de Yahvé, ¡si vuelves a mí!, ¡si quitas tus monstruos abominables, y de mí no huyes! Si juras por vida de Yahvé con verdad, derecho y justicia, en él serán benditas las naciones, en él se glorificarán (Jr 2,1-3.32-33; 3,1.4-5.19.22; 4,1-2).

\subsection{Dios llama a confiar en la desesperanza}

Dios da señales continuas de su presencia y llama a su pueblo y a la humanidad a confiar contra toda esperanza, en situaciones desesperadas. El ataque de los ejércitos unificados de Israel y de Siria contra Judá, en la llamada guerra siroefraimita, provoca una gran desconfianza respecto al futuro. Entonces, Isaías llama al rey de Judá a la confianza. Su llamada se fundamenta en las señales que Dios va dando de su presencia.

En tiempo de Ajaz [...] subió Rasón, rey de Aram, con Pécaj [...], rey de Israel, a Jerusalén, para atacarla [...]. La casa de David había recibido este aviso: "Aram se ha unido con Efraín", y se estremeció el corazón del rey y el corazón de su pueblo, como se estremecen los árboles del bosque por el 
viento. Entonces, Yahvé dijo a Isaías: "Ea, sal con tu hijo Sear Yasub al final del caño de la alberca superior, por la calzada del campo del Batanero, al encuentro de Ajaz, y dile: ¡Alerta, pero ten calma! No temas ni desmaye tu corazón por ese par de cabos de tizones humeantes. Aunque Aram, Efraín y el hijo de Romelías han maquinado tu ruina diciendo: Subamos contra Judá y desmembrémoslo, abramos brecha en él y pongamos allí por rey al hijo de Tabel", así ha dicho el Señor Yahvé: "No se mantendrá, ni será así; porque [todos saben que] la cabeza [capital] de Aram es Damasco, y cabeza de Damasco, Rasón; la cabeza [capital] de Efraín es Samaria, y el cabeza de Samaria, el hijo de Romelías [la cabeza de Judá es Jerusalén, y el cabeza de Jerusalén, Dios]. Pues bien: [dentro de unos años,] Efraín dejará de ser pueblo. Pero si no ponen la confianza en mí, no se mantendrán firmes (Is 7,1-9).

Volvió Yahvé [Isaías, cfr. Targum] a hablar a Ajaz:

- Pide para ti una señal de Yahvé tu Dios, en lo profundo del Seol o en lo más alto.

Dijo Ajaz:

- No la pediré, no tentaré a Yahvé.

Dijo Isaías:

- Oigan, pues, casa de David: ¿Les parece poco cansar a los hombres, que también cansan a mi Dios? Pues bien, el Señor mismo va a darles una señal: He aquí que la joven [la esposa del rey] está encinta y está a punto de dar a luz un hijo, al que pondrá por nombre Emmanuel. En su niñez, comerá alimentos de gracia; pero, antes de que salga de su niñez, quedarán hechos una desolación los territorios de quienes te hacen la guerra [...] Después, Yahvé atraerá sobre ti y sobre tu pueblo, y sobre la casa de tu padre, días como no los ha habido desde aquel en que se separaron Efraín y Judá (Is 7,10-17).

\subsection{Dios es solidario con el sufrimiento humano}

Dios se solidariza con el sufrimiento del pueblo y de la humanidad por medio de su Siervo íntimo y sufriente. El pueblo se preguntó por la actitud de Dios ante sus sufrimientos, sobre todo, después de los desastres que le sobrevinieron con la destrucción de Jerusalén por los babilonios y el exilio de muchos judíos en Babilonia. ¿Era Dios indiferente a sus desgracias? Realmente, ¿le afectaban? Pero ¿cómo algo así podía afectar a un Dios que se mostraba todopoderoso y dispuesto a guiar a su pueblo en su retorno y la reconstrucción de Judá?

El Segundo Isaías reflexiona sobre esto y, desde su experiencia de cercanía con Dios, afirma que si bien el Dios todopoderoso no puede sufrir con el pueblo en cuanto tal, sí puede hacerlo por medio de alguien muy cercano e íntimo. Este se acerca solidaria y voluntariamente al pueblo para quitarle de encima su pesada 
carga. De hecho, él mismo asume el dolor y el sufrimiento del pueblo. Estas reflexiones se encuentran recogidas en los cuatro cantos del Siervo de Yahvé.

En el primer canto, Dios presenta a su Siervo. Luego, le habla directamente a él, lo hace como amigo íntimo y declara cuál es su misión, una misión relacionada con el pueblo de Dios y con todos los pueblos.

He aquí mi siervo a quien yo sostengo,

mi elegido en quien se complace mi alma.

He puesto mi espíritu sobre él:

dictará ley a las naciones.

No vociferará ni alzará el tono, y no hará oír en la calle su voz.

Caña quebrada no partirá,

y mecha mortecina no apagará.

Lealmente hará justicia;

no desmayará ni se quebrará

hasta implantar en la tierra el derecho,

y su instrucción atenderán las islas.

Así dice el Dios Yahvé, el que crea los cielos y los extiende,

el que hace firme la tierra y lo que en ella brota,

el que da aliento al pueblo que hay en ella,

y espíritu a los que por ella andan.

Yo, Yahvé, te he llamado en justicia,

te así de la mano, te formé,

$\mathrm{y}$ te he destinado a ser alianza del pueblo y luz de las gentes,

para abrir los ojos ciegos,

para sacar del calabozo al preso, de la cárcel a los que viven en tinieblas (Is $42,1-7$ ).

En el segundo canto, el Siervo se dirige a todos los pueblos para compartir cómo ha sentido su relación íntima con Yahvé, la llamada llena de cariño y el gran apoyo experimentado, en medio de las dificultades en el desempeño de su misión, nacional e internacional.

¡Oídme, islas, atended, pueblos lejanos! Yahvé desde el seno materno me llamó;

desde las entrañas de mi madre recordó mi nombre.

Hizo mi boca como espada afilada, en la sombra de su mano me escondió; me hizo como saeta aguda, en su estuche me guardó.

Me dijo: "Tú eres mi siervo, en quien me gloriaré".

Efectivamente, yo me sentía glorificado a los ojos de Yahvé, mi Dios era mi fuerza.

Pues cuando yo decía: "Por poco me he fatigado, en vano e inútilmente mi vigor he gastado. ¿De veras que Yahvé se ocupa de mi causa, y mi Dios de mi trabajo?", 
me di cuenta de lo que me dice Yahvé, el que me plasmó desde el seno materno para siervo suyo, para hacer que Jacob vuelva a él y que Israel se le una:

"Poco es que seas mi siervo, en orden a levantar las tribus de Jacob, y hacer volver los sobrevivientes de Israel.

Te voy a poner como luz de los pueblos, para que mi salvación alcance hasta los confines de la tierra" (Is 49,1-6).

En el tercer canto, el Siervo vuelve hablar y manifiesta su cercanía a Dios, su docilidad pronta para cumplir la misión, aunque esta conlleve peligros y persecuciones, y su gran confianza en que Yahvé no lo defraudará.

El Señor Yahvé me ha dado lengua dócil, que sabe decir al cansado, palabras de aliento. Temprano, temprano despierta mi oído para escuchar, igual que los discípulos. El Señor Yahvé me ha abierto el oído. Y yo no me resistí, ni me hice atrás. Ofrecí mis espaldas a los que me golpeaban, mis mejillas a los que mesaban mi barba. Mi rostro no hurté a los insultos y salivazos.

Pues tenía la seguridad de que Yahvé me iba a ayudar para no caer víctima de los insultos, puse mi cara como el pedernal, sabiendo que no quedaría avergonzado.

Cerca está el que me justifica: ¿quién disputará conmigo?

Presentémonos juntos: ¿quién es mi demandante?, ¡que se llegue a mí!

He aquí que el Señor Yahvé me ayuda: ¿quién me condenará?

Pues todos ellos como un vestido se gastarán, la polilla se los comerá (Is 50,4-9).

En el último canto, intervienen varios actores. El canto tiene cuatro secciones. En la primera y la última, Dios habla para confirmar que el Siervo, después de experimentar el dolor y de haber llegado a sus profundidades, saldrá victorioso, enaltecido y lleno de vida. El camino está lleno de dificultades, pero en el horizonte brillará la luz. En la segunda sección, la comunidad del pueblo toma la palabra para hacer un repaso de la vida del Siervo y de sus dolores. Entonces, descubre que el sufrimiento con el que este ha sido golpeado ha sido aceptado voluntaria y solidariamente para acompañarlo en el suyo, pero sin merecerlo. La tercera sección parece recoger la reflexión teológica del profeta sobre lo vivido por el Siervo. En ella, insiste en la intimidad de este con Yahvé, en su inocencia, en su aceptación voluntaria y solidaria del sufrimiento, y en la vida que surge de dicho sufrimiento y de la muerte.

Mi Siervo prosperará, será enaltecido, levantado y exaltado por encima de todo.

Así como la multitud se quedó perpleja

- pues tan desfigurado tenía el aspecto, que no parecía una persona humana-, 
otro tanto se admirarán todas las naciones y no podrán hablar los reyes; pues lo que nunca se les contó verán y lo que nunca oyeron reconocerán. ¿Quién dio crédito a nuestra noticia? Y el brazo de Yahvé, ¿a quién se le reveló?

Creció como un retoño delante de él, como raíz de tierra árida.

No tenía apariencia ni presencia; le vimos y no tenía aspecto que pudiésemos estimar. Despreciado, marginado, hombre doliente y enfermizo, como de taparse el rostro por no verle. Despreciable, un Don Nadie.

¡Y con todo, eran nuestras dolencias las que él llevaba y nuestros dolores los que soportaba!

Nosotros le tuvimos por azotado, castigado y humillado por Dios.

Pero en realidad, ahora sabemos que ha sido herido por nuestras rebeldías, molido por nuestras culpas. Él soportó el castigo que nos trae la paz, y con sus moratones hemos sido curados.

Todos nosotros, como ovejas, nos desviamos, cada uno marchó por su camino, y Yahvé descargó sobre él la culpa de todos nosotros.

Fue oprimido, y él se humilló y no abrió la boca.

Como un cordero, al degüello era llevado,

y como oveja que ante los que la trasquilan está muda, tampoco él abrió la boca.

Tras arresto y juicio fue arrebatado, y de sus contemporáneos, ¿quién se preocupa?

Fue arrancado de la tierra de los vivos; por las rebeldías de su pueblo ha sido herido;

y se puso su sepultura entre los malvados y con los ricos su tumba, por más que no hizo atropello ni hubo engaño en su boca.

Pero le agradó a Yahvé quebrantarle con dolencias.

Ya que se da a sí mismo en expiación, verá descendencia, alargará sus días, y lo que quiera Yahvé se cumplirá por su mano.

Por las fatigas de su alma, verá luz, se saciará.

Por su conocimiento, justificará mi Siervo a muchos, y las culpas de ellos él soportará.

Por eso, le daré su parte entre los grandes y con poderosos repartirá despojos, ya que indefenso se entregó a la muerte y con los rebeldes fue contado, cuando él llevó el pecado de muchos e intercedió por los rebeldes (Is $52,13-53,12$ ).

En último término, los cantos del Siervo de Yahvé afirman que Dios no ha abandonado a su pueblo al sufrimiento, sino que, por medio de su amigo íntimo, lo acompaña de cerca. 


\subsection{Dios llama a una salvación universal}

La elección de los grupos marginados y oprimidos para formar con ellos un pueblo, el pueblo de la alianza con Dios, siempre tuvo como finalidad la realización de una misión universal. Ese pueblo estaba llamado a dar testimonio ante todos los pueblos de un Dios liberador, a quien todos debían llegar a conocer. Pero, frecuentemente, el pueblo "elegido" tiende a cerrarse en sí mismo. Cree, entonces, que la elección es un privilegio y no una responsabilidad. Esta tentación es más fuerte después del exilio en Babilonia. Oprimido por otros pueblos, no tiene disposición para cumplir con su misión universal. Se niega a relacionarse positivamente con los otros pueblos.

Por esa razón, los profetas de la época se sienten llamados a defender la universalidad de la salvación. La escuela de Isaías habla del futuro como un afluir de todos los pueblos hacia la montaña del Señor. Él, por medio de su pueblo, les enseñará sus caminos, los cuales pasan por la paz universal y cósmica.

Sucederá en días futuros que el monte de la Casa de Yahvé será asentado en la cima de los montes y se alzará por encima de las colinas.

Confluirán a él todas las naciones, y acudirán pueblos numerosos. Dirán: "¿Ea!, subamos al monte de Yahvé, a la Casa del Dios de Jacob, para que él nos enseñe sus caminos y nosotros sigamos sus senderos. Pues de Sion saldrá la Ley, y de Jerusalén la palabra de Yahvé.

Juzgará entre las gentes, será árbitro de pueblos numerosos. Forjarán de sus espadas azadones, y de sus lanzas podaderas. No levantará espada nación contra nación, ni se ejercitarán más en la guerra" (Is 2,2-4).

En Isaías 56, se habla de que todo mortal, todo extranjero y todo eunuco es llamado a formar parte del pueblo de Dios, a velar por la igualdad y a practicar la justicia, pues la salvación de Dios está por llegar a todos los pueblos.

Así dice Yahvé: Velen por la equidad y practiquen la justicia, que mi salvación está para llegar y mi justicia para manifestarse.

Dichoso el mortal que tal haga, el hombre que persevere en ello, guardándose de profanar el sábado, guardando su mano de hacer nada malo.

Que el extranjero que se adhiera a Yahvé, no diga: “¡De cierto que Yahvé me separará de su pueblo!". No diga el eunuco: "Soy un árbol seco".

Pues así dice Yahvé: Respecto a los eunucos que guardan mis sábados y eligen aquello que me agrada y se mantienen firmes en mi alianza, yo he de darles en mi Casa y en mis muros monumento y nombre mejor que hijos e hijas; nombre eterno les daré que no será borrado.

En cuanto a los extranjeros adheridos a Yahvé para su ministerio, para amar el nombre de Yahvé, y para ser sus siervos, a todo aquel que guarda el sábado 
sin profanarle y a los que se mantienen firmes en mi alianza, yo les traeré a mi monte santo y les alegraré en mi Casa de oración. Sus holocaustos y sacrificios serán gratos sobre mi altar. Porque mi Casa será llamada Casa de oración para todos los pueblos.

Oráculo del Señor Yahvé, que reúne a los dispersos de Israel. A los ya reunidos, todavía añadiré otros (Is 56,1-8).

Isaías 66 anuncia que el Señor viene a reunir a todas las naciones y lenguas para que vean la gloria de Dios y para elegir entre ellas a quienes la anuncien y a quienes serán sus ministros.

Yo vengo a reunir a todas las naciones y lenguas; vendrán y verán mi gloria.

Les pondré una señal y enviaré de ellos algunos escapados [convertidos] a las naciones [...]; a las islas remotas que no oyeron mi fama ni vieron mi gloria. Ellos anunciarán mi gloria a las naciones. Y traerán a todos los hermanos de ustedes de todas las naciones, como oblación a Yahvé -en caballos, carros, literas, mulos y dromedarios-, a mi monte santo de Jerusalén - dice Yahvé-, como traen los hijos de Israel la oblación en recipiente limpio a la Casa de Yahvé. Y también de entre ellos tomaré para sacerdotes y levitas -dice Yahvé (Is 66,18-21).

En consecuencia, la liberación, la salvación y la visión de la gloria de Dios no se limitan al pueblo elegido, sino que están abiertas a todos los pueblos y a todas las naciones.

\subsection{Dios llama a un nuevo mundo en justicia y en paz}

A medida que la historia del pueblo de Dios se alarga, que las dificultades para sobrevivir son mayores y que el mundo del mal, de la injusticia, de la violencia y del egoísmo parece imponerse sobre el bien, la justicia, la paz y la generosidad en el servicio, la esperanza parece perder terreno. En ese contexto, los profetas descubren con más fuerza los sueños y la esperanza de Dios: una humanidad sin opresión, sin violencia, sin guerras, sin injusticias, sin muerte. En consecuencia, anuncian la novedad del mundo de Dios, que hará una nueva alianza, pero esta vez en el corazón humano. En efecto, Dios dará a la humanidad un corazón de carne y creará un nuevo cielo y una nueva tierra. Los siguientes textos hablan por sí mismos.

Isaías, durante la guerra de Siria e Israel contra Judá:

Porque el yugo que les pesaba y la vara que los oprimía has roto, como el día de Madián. Porque toda bota militar y el uniforme lleno de sangre de los soldados serán para la quema, pasto del fuego. Porque una criatura nos ha nacido, un hijo se nos ha dado. Estará el señorío sobre su hombro, y recibirá los títulos de "Maravilla de Consejero", "Dios Fuerte", "Siempre Padre", 
"Príncipe de Paz". Grande es su señorío y la paz no tendrá fin sobre el trono de David y sobre su reino, para restaurarlo y consolidarlo por la equidad y la justicia. Desde ahora y hasta siempre, el celo de Yahvé Sebaot hará eso (Is 9,3-6).

[El ungido de Yahvé] no juzgará por las apariencias, ni sentenciará de oídas. Juzgará con justicia a los débiles, y sentenciará con rectitud a los pobres de la tierra. Herirá al hombre cruel con la vara de su boca, con el soplo de sus labios acabará con el malvado.

Justicia será el cincho de su cintura, verdad el cinturón de sus flancos.

Serán vecinos el lobo y el cordero, y el leopardo se echará con el cabrito, el novillo y el cachorro pacerán juntos, y un niño pequeño los conducirá.

La vaca y la osa pacerán, juntas acostarán sus crías, el león, como los bueyes, comerá paja.

Hurgará el niño de pecho en el agujero del áspid, y en el nido de la víbora el recién destetado meterá la mano.

Nadie hará daño, nadie hará mal en todo mi santo Monte, porque la tierra estará llena de una auténtica relación con Yahvé, como cubren las aguas el mar (Is 11,3-9).

Miqueas desarrolla las esperanzas formuladas en su oráculo sobre Belén:

Y sucederá aquel día que yo extirparé de en medio de ti tus caballos, y haré desaparecer tus carros de combate; extirparé las ciudades fortificadas de tu tierra, y demoleré todas tus fortalezas; extirparé de tu mano las hechicerías, y no habrá para ti más adivinos; extirparé tus estatuas y tus estelas de en medio de ti, y ya no podrás postrarte más ante la obra de tus manos (Mi 5,9-12).

Jeremías, durante su primera actividad en su pueblo de Anatot:

He aquí que días vienen en que yo pactaré con la casa de Israel (y con la casa de Judá) una nueva alianza; no como la alianza que pacté con sus padres, cuando los tomé de la mano para sacarlos de Egipto; que ellos rompieron mi alianza, y yo hice estrago en ellos.

Sino que esta será la alianza que yo pacte con la casa de Israel, después de aquellos días: pondré mi Ley en su interior y sobre sus corazones la escribiré, y yo seré su Dios y ellos serán mi pueblo.

Ya no tendrán que adoctrinar más el uno a su prójimo y el otro a su hermano, diciendo "Amen a Yahvé", pues todos ellos me amarán, del más chico al más grande, y la señal de esta alianza se dará cuando yo, Yahvé, perdone su culpa, y de su pecado no vuelva a acordarme (Jr 31,31-34).

Ezequiel, después de la caída de Jerusalén:

Y les daré un corazón nuevo, infundiré en ustedes un espíritu nuevo, quitaré de su carne el corazón de piedra y les daré un corazón de carne. Infundiré mi 
espíritu en ustedes y haré que vivan según mis preceptos y observen y practiquen mis normas. Habitarán la tierra que yo di a sus padres. Ustedes serán mi pueblo y yo seré su Dios (Ez 36,26-28).

El Segundo Isaías, durante el exilio: "el producto de la justicia será la paz, el fruto de la equidad, una seguridad perpetua" (Is 32,17).

El espíritu del Señor Yahvé está sobre mí, por cuanto que me ha ungido Yahvé. Me ha enviado a anunciar la buená nueva a los pobres, a vendar los corazones rotos, a proclamar la liberación a los cautivos y la libertad a los encarcelados; a pregonar año de gracia de Yahvé, día de venganza de nuestro Dios; para consolar a todos los que lloran (Is 61,1-2).

El Tercer Isaías, en el tiempo de la restauración posterior al exilio:

¿No será más bien este otro el ayuno que yo quiero: desatar los lazos de maldad, deshacer las coyundas del yugo, dar la libertad a los quebrantados, y arrancar todo yugo? ¿No será partir para el hambriento tu pan, y recibir en casa a los pobres sin hogar? ¿Que cuando veas a un desnudo le vistas, y de tu semejante no te apartes? (Is 58,6-7).

Pues he aquí que yo creo cielos nuevos y tierra nueva, y no serán mencionados los primeros ni vendrán a la memoria; antes, habrá gozo y regocijo por siempre jamás, por lo que voy a crear. Pues he aquí que yo voy a crear a Jerusalén con el nombre de "Regocijo" y a su pueblo con el nombre de "Alegría"; me regocijaré por Jerusalén y me alegraré por mi pueblo, sin que se oiga allí jamás lloro ni quejido. No habrá allí jamás niño que viva pocos días, o viejo que no llene sus días, pues morir joven será morir a los cien años, y el que no alcance los cien años será porque está maldito. Edificarán casas y las habitarán, plantarán viñas y comerán su fruto. No edificarán para que otro habite, no plantarán para que otro coma, pues cuanto vive un árbol vivirá mi pueblo, y mis elegidos disfrutarán del trabajo de sus manos. No se fatigarán en vano ni tendrán hijos para sobresalto, pues serán raza bendita de Yahvé ellos y sus retoños con ellos. Antes que me llamen, yo responderé; aún estarán hablando, y yo les escucharé. Lobo y cordero pacerán a una, el león comerá paja como el buey, y la serpiente se alimentará de polvo, no harán más daño ni perjuicio en todo mi santo monte - dice Yahvé (Is 65,17-25).

\subsection{Dios promete acompañar a su pueblo y a la humanidad}

Dios llama a su pueblo, desde su fundación, a realizar en la historia su proyecto liberador. Esa llamada descansa en la convicción de fe de que Dios se ha comprometido a "estar siempre con él", hasta el final de los tiempos. Por eso, Dios se presenta, desde el principio, como "el que siempre estará". En efecto, a lo largo de su historia, el pueblo siente la presencia constante de Dios a su lado y la llamada a transmitir a la humanidad esa experiencia de acompañamiento 
cercano. Los profetas formulan de diversas formas esa presencia, pero todas dicen lo mismo.

El buen pastor de Jeremías y Ezequiel:

Yo recogeré el Resto de mis ovejas de todas las tierras a donde las empujé, las haré tornar a sus estancias, criarán y se multiplicarán. Y pondré al frente de ellas pastores que las apacienten, y nunca más estarán medrosas ni asustadas, ni faltará ninguna. Miren que días vienen en que suscitaré a David un Germen justo: reinará un rey prudente, practicará el derecho y la justicia en la tierra. En sus días, estará a salvo Judá, e Israel vivirá en seguro. Y este ungido recibirá el nombre de "Yahvé, justicia nuestra" (Jr 23,3-6).

Yo suscitaré para ponérselo al frente un solo pastor que las apacentará, mi siervo David: él las apacentará y será su pastor. Yo, Yahvé, seré su Dios, y mi siervo David será príncipe en medio de ellos. Yo, Yahvé, he hablado. Concluiré con ellos una alianza de paz, haré desaparecer de esta tierra las bestias feroces. Habitarán en seguridad en el desierto y dormirán en los bosques. Yo los asentaré en los alrededores de mi colina, y mandaré a su tiempo la lluvia, que será una lluvia de bendición. El árbol del campo dará su fruto, la tierra dará sus productos, y ellos vivirán en seguridad en su suelo. Y sabrán que yo soy Yahvé, cuando despedace las barras de su yugo y los libre de la mano de los que los tienen esclavizados. No volverán a ser presa de las naciones, las bestias salvajes no volverán a devorarlos. Habitarán en seguridad y no se les turbará más. Haré brotar para ellos un plantío famoso; no habrá más víctimas del hambre en el país, ni sufrirán más el ultraje de las naciones.

Y sabrán que yo, Yahvé, su Dios, estoy con ellos, y que ellos, la casa de Israel, son mi pueblo, oráculo del Señor Yahvé. Ustedes, mis ovejas, son el rebaño humano que yo apaciento, y yo soy su Dios, oráculo del Señor Yahvé (Ez 34,17-31).

La consolación y la buena noticia del retorno en el Segundo Isaías:

Consuelen, consuelen a mi pueblo - dice su Dios. Hablen al corazón de Jerusalén y díganle bien alto que ya ha cumplido su milicia, ya ha satisfecho por su culpa, pues ha recibido de mano de Yahvé castigo doble por todos sus pecados. Una voz clama: "En el desierto abran camino a Yahvé, tracen en la estepa una calzada recta a nuestro Dios. Que todo valle sea elevado, y todo monte y cerro rebajado; vuélvase lo escabroso llano, y las breñas planicie. Se revelará la gloria de Yahvé, y toda criatura a una la verá. Pues la boca de Yahvé ha hablado".

Una voz dice: “'Grita!”. Y digo: “Qué he de gritar?”. “Toda carne es hierba y todo su esplendor como flor del campo. La flor se marchita, se seca la hierba, en cuanto le dé el viento de Yahvé (pues, cierto, hierba es el pueblo). La 
hierba se seca, la flor se marchita, mas la palabra de nuestro Dios permanece por siempre".

Súbete a un alto monte, alegre mensajero para Sion; clama con voz poderosa, alegre mensajero para Jerusalén, clama sin miedo. Di a las ciudades de Judá: "Ahí está su Dios. Ahí viene el Señor Yahvé con poder, y su brazo lo sojuzga todo. Vean que su salario le acompaña, y su paga le precede. Como pastor, pastorea su rebaño: recoge en brazos los corderitos, en el seno los lleva, y trata con cuidado a las paridas" (Is 40,1-11).

Y tú, Israel, siervo mío, Jacob, a quien elegí, simiente de mi amigo Abraham; que te así desde los cabos de la tierra, y desde lo más remoto te llamé y te dije: "Siervo mío eres tú, te he escogido y no te he rechazado": No temas, que contigo estoy yo; no receles, que yo soy tu Dios. Yo te he robustecido y te he ayudado, y te tengo asido con mi diestra justiciera.

¡Oh! Se avergonzarán y confundirán todos los abrasados en ira contra ti. Serán como nada y perecerán los que buscan querella. Los buscarás y no los hallarás a los que disputaban contigo. Serán como nada y nulidad los que te hacen la guerra. Porque yo, Yahvé, tu Dios, te tengo asido por la diestra. Soy yo quien te digo: "No temas, yo te ayudo". No temas, gusano de Jacob, gente de Israel: yo te ayudo-oráculo de Yahvé-, y tu redentor es el Santo de Israel.

He aquí que te he convertido en trillo nuevo, de dientes dobles. Triturarás los montes y los desmenuzarás, y los cerros convertirás en tamo. Los beldarás, y el viento se los llevará, y una ráfaga los dispersará. Y tú te regocijarás en Yahvé, en el Santo de Israel te gloriarás. Los humildes y los pobres buscan agua, pero no hay nada. La lengua se les secó de sed. Yo, Yahvé, les responderé, Yo, Dios de Israel, no los desampararé. Abriré sobre los calveros arroyos y en medio de las barrancas manantiales. Convertiré el desierto en lagunas y la tierra árida en hontanar de aguas. Pondré en el desierto cedros, acacias, arrayanes y olivares. Pondré en la estepa el enebro, el olmo y el ciprés a una, de modo que todos vean y sepan, adviertan y consideren que la mano de Yahvé ha hecho eso, el Santo de Israel lo ha creado (Is 41,8-20).

Así dice Yahvé, que trazó camino en el mar, y vereda en aguas impetuosas. El que hizo salir carros y caballos a una con poderoso ejército; a una se echaron para no levantarse, se apagaron, como mecha se extinguieron.

¿No se acuerdan de lo pasado, ni caen en la cuenta de lo antiguo? Pues bien, he aquí que yo lo renuevo: ya está en marcha, ¿no lo reconocen? Sí, pongo en el desierto un camino, ríos en el páramo. Las bestias del campo me darán gloria, los chacales y las avestruces, pues pondré agua en el desierto (y ríos en la soledad) para dar de beber a mi pueblo elegido. El pueblo que yo me he formado contará mis alabanzas (Is 43,16-21). 


\section{Apéndice: las tradiciones apocalípticas}

Las tradiciones apocalípticas aparecen en tiempo de crisis fuerte, con la idea de ayudar a superarlo. Aquí me refiero a las tradiciones que surgen en torno a la opresión helenista-seléucida. La característica más destacada de estas tradiciones es la visión de un personaje significativo, interpretada por un ángel. La visión y su respectiva interpretación pretenden iluminar la situación de crisis y animar a la fidelidad. Frecuentemente, las visiones son acompañadas de relatos ejemplarizantes, en los cuales algunos personajes se mantienen fieles, incluso al borde de la muerte. Por eso, en último término, Dios los salva.

Las visiones y los relatos ejemplares constituyen una literatura clandestina de resistencia, razón por la cual se recurre a técnicas que impiden identificar al autor. Los escritos debían llegar a sus destinatarios, agobiados por grandes dificultades. Una de las técnicas utilizadas es el pseudónimo. Los autores atribuyen el escrito a un personaje famoso del pasado, lo cual, además de ocultar su identidad, otorga mayor autoridad al mensaje. Otra técnica es el lenguaje cifrado en números o en símbolos, como las partes del cuerpo, los lugares, los animales, el vestido, los colores, etc., que solo los iniciados comprenden. Una tercera técnica consiste en relatar una revelación, en forma de sueño o visión, que debe ser interpretada por un ángel.

La última técnica es el llamado "salto de pértiga", en referencia al saltador, que se aleja del obstáculo, emprende una carrerilla y se impulsa hacia el listón con ayuda de la pértiga. De modo similar, el escritor apocalíptico, que desea ayudar a sus lectores a superar una dificultad, los remite al pasado histórico y les muestra cómo había habido varias situaciones parecidas de mucho sufrimiento, las cuales habían sido superadas. De igual modo, el obstáculo actual también sería vencido. Por tanto, deben mantener el ánimo y la esperanza.

\subsection{El libro de Daniel}

El único libro claramente apocalíptico del Antiguo Testamento es el de Daniel. El libro anima a la resistencia para volver a vivir de acuerdo al proyecto liberador de Dios. Aunque la acción narrada en el libro se sitúa en la época de la dominación de los imperios babilonio y medo-persa (587-500 a. C.) sobre los judíos, en realidad, el texto fue elaborado en tiempos de la opresión del imperio griego, helenista. En concreto, en los últimos años del reinado del seléucida Antíoco IV (175-164 a. C.).

La acción narrada transcurre en los años del imperio babilonio (587-500) y los del comienzo del imperio persa. Los relatos y las visiones de Daniel se sitúan en los reinados de Nabucodonosor (605-562) - los cuatro primeros relatos-; Baltasar, quien solo gobierna diez días, en ausencia de su padre - el quinto relato y las dos primeras visiones-; Darío el Medo, de quien no hay constancia histó- 
rica -el sexto relato y la tercera visión-; y Ciro el Medo Persa (555-530) - la cuarta visión y quizás el relato griego de Susana y de Bel y el Dragón.

Sin embargo, existen incoherencias históricas significativas. El libro habla del rey Baltasar como hijo de Nabucodonosor, pero aquel no llega a reinar y no es hijo de este último, sino de Nabonid (556-539), el último rey babilonio. El sexto relato refiere a la época del rey Darío el Medo, cuyo reinado habría tenido lugar entre el de Nabonid y el del medo-persa Ciro, pero no existe registro histórico alguno de tal rey. Además, supone la existencia de un corte entre el quinto relato y las dos primeras visiones, ocurridas en tiempos de Baltasar. Estas inexactitudes históricas hacen pensar que el autor de Daniel desconocía muchos datos de los imperios babilonio y medo-persa. En realidad, escribe tres siglos más tarde.

Así, pues, el contexto histórico del libro de Daniel debe situarse entre el año 167, cuando se agudiza la persecución de Antíoco IV, y el año 164, cuando la rebelión macabea lo derrota. De hecho, el autor proporciona muchos datos precisos, que permiten reconstruir la historia de esa época, y, en cambio, generaliza mucho y comete imprecisiones y errores cuando habla de Babilonia y de Persia.

El libro relata en lenguaje cifrado el asesinato del sumo sacerdote Onías III, el intento de helenización cultural y religiosa, la entronización de Zeus en el templo, el asentamiento de una guarnición griega en Sion, la tributación, la imposición de costumbres griegas y el disimulo de la circuncisión. También habla, con el mismo lenguaje cifrado, del levantamiento armado de algunos fieles, el cual provoca la guerra de guerrillas, que da el triunfo a los macabeos y permite la instauración de la monarquía hasmonea; y de la resistencia pasiva de otros fieles, dispuestos a dar la vida por su fe y sus costumbres.

\subsection{Análisis del libro}

La intención del autor apocalíptico es fortalecer a quienes resisten de un modo u otro. Tanto los relatos como las visiones apuntan en esa dirección: animar a resistir, suscitar esperanza y anunciar un futuro, donde el proyecto liberador de Dios sea vivido en plenitud.

El texto tiene tal mezcla de géneros - relato, profecía y enseñanza sapiencial-y de idiomas - hebreo sagrado, arameo popular y griego oficial-, que muchos piensan que se trataría de varias obras independientes. Otros, en cambio, opinan que tal vez el autor deseaba llegar a la mayor cantidad posible de lectores y por eso recurre a tantos géneros e idiomas. A pesar de que el libro está conformado por seis relatos sencillos, que hablan de Daniel y sus amigos, en la corte de Babilonia, por cuatro visiones más complejas y por dos relatos en griego añadidos, el conjunto es muy consistente.

Los relatos primero (hebreo), tercero (arameo), sexto (arameo), séptimo (griego) y octavo (griego) afirman que Dios siempre está al lado de quien es fiel 
y, por eso, lo libra de la muerte. Los relatos pretenden animar a quienes resisten las presiones. De esa manera, el primer relato habla de la fidelidad de Daniel y de los tres jóvenes a las costumbres alimenticias judías y de su negativa a contaminarse. Dios premia su actitud haciendo que aparezcan mucho más saludables que los que habían comido lo que estaba prohibido a los judíos. El tercer relato narra cómo los tres jóvenes judíos se niegan a adorar la estatua de Nabucodonosor y cómo Dios los libra del horno de fuego, al cual habían sido lanzados por su fidelidad. En el sexto relato, Dios salva a Daniel del foso de los leones, a donde había sido arrojado por la misma razón. De nuevo, Dios premia la fidelidad judía.

El relato griego de Susana narra cómo esta joven es acusada falsamente de adulterio por no acceder a los malos deseos de dos ancianos. Pero gracias a la sabiduría de Daniel, se libra de la muerte. Dios salva a quien es fiel a la ley. El otro relato griego, el de Bel y el Dragón, narra cómo Daniel convence a Ciro de que Bel es un dios sin vida, al desenmascarar las trampas usadas por los sacerdotes para demostrar lo contrario. Así, la estatua de Bel es destruida. Además, Daniel apuesta con Ciro, y gana, que puede acabar con el Dragón sin usar arma alguna. Ante las presiones de los adoradores de Bel y del Dragón, Ciro lo condena a morir en la cueva de los leones, pero Dios lo salva por su fidelidad.

En los otros relatos - el segundo (arameo), el cuarto (arameo) y el quinto (arameo)-, y en las cuatro visiones - la primera en arameo y las otras tres en hebreo-, se afirma que el proyecto de Dios contempla la destrucción de los imperios y de toda borrachera de poder, y la instauración de un tiempo definitivo, bajo su reinado mesiánico.

En efecto, en el cuarto relato, Daniel interpreta el sueño del árbol abatido y afirma que Dios acabará con la borrachera de poder de Nabucodonosor, que vagará por el desierto como loco entre los animales, hasta que reconozca la grandeza y el poder de Dios. El quinto relato narra que en un banquete sacrílego del soberbio y arrogante Baltasar, una mano pinta en el mundo tres palabras, las cuales indican tres monedas de valor decreciente. La interpretación de Daniel asegura, de manera amenazadora y pesimista, que se trata del valor decreciente de los imperios - Babilonia, Media y Persia-, o bien del futuro catastrófico de Baltasar, cuyo sucesor será Darío el Medo.

El segundo relato narra el sueño de la estatua con cabeza de oro, pecho y brazos de plata, vientre y lomos de bronce, piernas de hierro y pies mitad de hierro y mitad de barro. Una roca, desprendida de la montaña, sin intervención humana, destruye la estatua. El mensaje dice que los imperios -Babilonia, Media, Persia, Alejandro, ptolomeos y seléucidas- se quiebran por obra de Dios. Este relato está íntimamente relacionado con las cuatro visiones que vienen a continuación. 
La primera visión, la de las bestias, las cuales se suceden hasta que, desde el cielo, llega alguien con figura de ser humano e instaura el reinado de los santos del altísimo, habla de un Dios que interviene para acabar con los imperios - Babilonia, Media, Persia, Alejandro y la dinastía seléucida (Antíoco IV). La segunda visión es la de un carnero con dos cuernos, vencido por el macho cabrío, al cual le salen cuatro cuernos. De uno de esos cuernos nace otro, que arrogantemente se atreve a atacar a Dios, pero al final, es vencido. La visión insiste en que los imperios son vencidos - Persia y Media; Alejandro, cuyo imperio se divide en cuatro partes; y Antíoco IV-, porque el tiempo de la cólera de Dios ha llegado.

La tercera visión se fundamenta en el anuncio de Jeremías de que después de los setenta años, vendría la restauración posterior al exilio. Así, pues, aparentemente, la visión señalaría cuándo ocurrirá el triunfo final del reinado de Dios y de su ungido. Sin embargo, el texto admite tres lecturas. La primera, más ingenua y mesiánica, refiere la profecía a Jesús. Daniel habría previsto cuándo vendría, pero esta lectura solo puede sostenerse si se violentan los datos históricos. La segunda, más crítica, niega la interpretación mesiánica. Según esta, se trata de un anuncio apocalíptico sobre la destrucción de los imperios, en particular, el de Antíoco IV. La tercera lectura distingue entre Daniel 9,24, que habla, mesiánica y proféticamente, de "la consagración del santo de los santos", esto es, de la purificación del templo, ocurrida (164 a. C.) como símbolo de la instauración definitiva del reinado de Dios; y Daniel 9,25-28, que propone una visión apocalíptica de la historia, desde el exilio hasta el final de Antíoco IV, pasando por la reconstrucción del templo durante los persas, el asesinato de Onías III (171 a. C.), la opresión de Antíoco IV, la alianza de este con los desertores, y la supresión de los sacrificios y la entronización de Zeus en el templo.

La cuarta visión, conocida como "la gran visión", contiene un recuento muy detallado de la historia de Judá y de sus relaciones con Persia y Grecia, de las guerras entre lágidas y seléucidas, y de la opresión y el orgullo de Antíoco IV, de sus guerras y su muerte. La visión concluye con el anuncio del final de los tiempos difíciles, la salvación de los inscritos en el libro y la resurrección de los justos para la vida eterna.

Así, pues, la tradición apocalíptica insiste en que el proyecto liberador de Dios seguirá siendo una realidad, gracias a su intervención directa en la historia. Esa intervención acabará con el imperio perseguidor, de la misma manera como ha acabado con todos los imperios opresores y perseguidores, e instaurará el imperio definitivo. Por consiguiente, las dificultades deben ser enfrentadas con esperanza, mientras se mantienen las tradiciones de la fe y las costumbres. Tanto las tradiciones proféticas como las apocalípticas mantienen el proyecto liberador de Dios, pero lo actualizan continuamente para mostrar, en cada situación, su dimensión humana y ennoblecedora. 